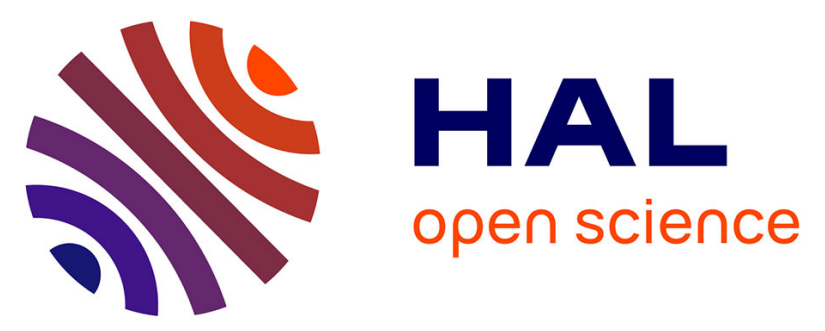

\title{
Deep pre-eruptive storage of silicic magmas feeding Plinian and dome-forming eruptions of central and northern Dominica (Lesser Antilles) inferred from volatile contents of melt inclusions
}

Hélène Balcone-Boissard, G. Boudon, J. Blundy, Caroline Martel, R. Brooker, E. Deloule, C. Solaro, V. Matjuschkin

\section{To cite this version:}

Hélène Balcone-Boissard, G. Boudon, J. Blundy, Caroline Martel, R. Brooker, et al.. Deep pre-eruptive storage of silicic magmas feeding Plinian and dome-forming eruptions of central and northern Dominica (Lesser Antilles) inferred from volatile contents of melt inclusions. Contributions to Mineralogy and Petrology, 2018, 173 (12), 24 p. 10.1007/s00410-018-1528-4 . insu-01934695

\section{HAL Id: insu-01934695 \\ https://hal-insu.archives-ouvertes.fr/insu-01934695}

Submitted on 19 Jul 2019

HAL is a multi-disciplinary open access archive for the deposit and dissemination of scientific research documents, whether they are published or not. The documents may come from teaching and research institutions in France or abroad, or from public or private research centers.
L'archive ouverte pluridisciplinaire HAL, est destinée au dépôt et à la diffusion de documents scientifiques de niveau recherche, publiés ou non, émanant des établissements d'enseignement et de recherche français ou étrangers, des laboratoires publics ou privés. 


\title{
Deep pre-eruptive storage of silicic magmas feeding Plinian and dome-forming eruptions of central and northern Dominica (Lesser Antilles) inferred from volatile contents of melt inclusions
}

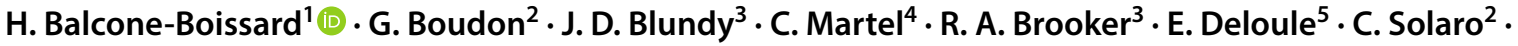 \\ V. Matjuschkin ${ }^{3,6}$
}

\begin{abstract}
Volatiles contribute to magma ascent through the sub-volcanic plumbing system. Here, we investigate melt inclusion compositions in terms of major and trace elements, as well as volatiles $\left(\mathrm{H}_{2} \mathrm{O}, \mathrm{CO}_{2}, \mathrm{SO}_{2}, \mathrm{~F}, \mathrm{Cl}, \mathrm{Br}, \mathrm{S}\right)$ for Quaternary Plinian and dome-forming dacite and andesite eruptions in the central and the northern part of Dominica (Lesser Antilles arc). Melt inclusions, hosted in orthopyroxene, clinopyroxene and plagioclase are consistently rhyolitic. Post-entrapment crystallisation effects are limited, and negligible in orthopyroxene-hosted inclusions. Melt inclusions are among the most water-rich yet recorded $\left(\leq 8 \mathrm{wt} \% \mathrm{H}_{2} \mathrm{O}\right) . \mathrm{CO}_{2}$ contents are generally low $(<650 \mathrm{ppm})$, although in general the highest pressure melt inclusion contain the highest $\mathrm{CO}_{2}$. Some low-pressure ( $<3 \mathrm{kbars}$ ) inclusions have elevated $\mathrm{CO}_{2}$ (up to 1100-1150 ppm), suggestive of fluxing of shallow magmas with $\mathrm{CO}_{2}$-rich fluids. $\mathrm{CO}_{2}$-trace element systematics indicate that melts were volatile-saturated at the time of entrapment and can be used for volatile-saturation barometry. The calculated pressure range (0.8-7.5 kbars) indicates that magmas originate from a vertically-extensive (3-27 km depth) storage zone within the crust that may extend to the sub-Dominica Moho $(28 \mathrm{~km})$. The vertically-extensive crustal system is consistent with mush models for sub-volcanic arc crust wherein mantle-derived mafic magmas undergo differentiation over a range of crustal depths. The other volatile range of composition for melt inclusions from the central part is $\mathrm{F}$ (75-557 ppm), $\mathrm{Cl}(1525-3137 \mathrm{ppm}), \mathrm{Br}(6.1-15.4 \mathrm{ppm})$ and $\mathrm{SO}_{2}(<140 \mathrm{ppm})$, and for the northern part it's $\mathrm{F}$ (92-798 ppm), $\mathrm{Cl}(1506-4428 \mathrm{ppm}), \mathrm{Br}$ (not determined) and $\mathrm{SO}_{2}(<569$; one value at $1015 \mathrm{ppm})$. All MIs, regardless of provenance, describe the same $\mathrm{Cl} / \mathrm{F}$ correlation $(8.3 \pm 2.7)$, indicating that the magma source at depth is similar. The high $\mathrm{H}_{2} \mathrm{O}$ content of Dominica magmas has implications for hazard assessment.
\end{abstract}

Keywords Melt inclusion $\cdot$ Volatiles $\cdot$ Arc magma $\cdot$ Dominica $\cdot$ Lesser Antilles arc

\section{Introduction}

Communicated by Othmar Müntener.

Electronic supplementary material The online version of this article (https://doi.org/10.1007/s00410-018-1528-4) contains supplementary material, which is available to authorized users.

H. Balcone-Boissard

helene.balcone_boissard@upmc.fr

1 Sorbonne Universités, UPMC Université Paris 06, CNRS, Institut des Sciences de la Terre de Paris (ISTeP), 4 place Jussieu, 75005 Paris, France

2 Institut de Physique du Globe de Paris, Sorbonne Paris Cité, Université Paris Diderot, CNRS, 75005 Paris, France

3 School of Earth Sciences, University of Bristol, Wills Memorial Building, Bristol BS8 1RJ, UK
Subduction zone volcanic rocks reflect diverse contributions to arc magma generation in terms of chemical modification of the mantle by recycled oceanic lithosphere (e.g.

4 Institut des Sciences de la Terre d'Orléans (ISTO), UMR 7327 Université d'Orléans-CNRS-BRGM, Orléans, France

5 CRPG, UMR 7358, CNRS, Université de Lorraine, BP 20, 54501 Vandoeuvre-lès-Nancy Cedex, France

6 Institut für Geowissenschaften, Goethe-Universität, Altenhöferallee 1, 60438 Frankfurt am Main, Germany 
Macdonald et al. 2000). The chemical diversity of arc magmas provides insights into crustal differentiation processes (Yanagida et al. 2018), whereas their magmatic volatiles afford clues to eruption dynamics and pre-eruptive magma storage conditions (Gurenko et al. 2005; Balcone-Boissard et al. 2010), a key parameter in developing a better evaluation of volcanic hazard, and in hydrothermal mineralization (Wilkinson 2013). The primary geochemical signature of erupted magmas is inherited ultimately from the mantle source region with subsequent modification and evolution during differentiation and pre-eruptive ascent and storage in the crust. The role of different components in generating the diversity of arc magma composition (e.g. fluids derived from subducted oceanic crust and sediments, crustal contamination) remains a matter of debate (Thirlwall et al. 1996; Blundy et al. 2008; Labanieh et al. 2012).

Volatiles play a major role in determining the eruptive style of magma, through the interplay of degassing with magma rheology and phase relations (Esposito et al. 2014). Characterization of volatile contents is essential in predicting the potential explosivity of magma, especially in a subduction context. Much of our understanding of magmatic volatile contents comes from melt inclusions (MI), small glassy pockets of magma trapped by phenocrysts during their growth, that preserve the pre-eruptive volatile content prior to eruption and degassing of the matrix. Carefully interpreted, MI data can help us to constrain the pre-eruptive conditions in terms of magma composition in major, trace and volatile elements (Moore 2008).

The aim of this work is to characterize the geochemical fingerprint of magmas responsible for the large pumiceous eruptions in the central part of Dominica (Lesser Antilles volcanic arc) as well as for those from the Morne aux Diables volcanic center in the northern part, by analysing MIs trapped in the major phenocrysts of the different eruptions, for the full spectrum of major, trace and volatile elements, including $\mathrm{H}_{2} \mathrm{O}, \mathrm{CO}_{2}, \mathrm{~F}, \mathrm{Cl}, \mathrm{Br}$ and $\mathrm{S}$. In addition, magma storage conditions at the scale of the Lesser Antilles arc are discussed.

\section{Geological context}

The Lesser Antilles arc results from the oblique subduction of the Atlantic sea floor (North and South American plates) beneath the Caribbean Plate at a mean convergence rate of $2 \mathrm{~cm} /$ year (Wadge 1984). The volcanic arc is $850 \mathrm{~km}$ long, extending from the island of Saba in the north to Grenada in the south, with an eastwards convexity. Dominica lies in the central part of the arc (Fig. 1a). North of Dominica the arc splits into two branches: the Outer or Older arc (Eocene to mid-Oligocene) and an Inner or Recent arc (Miocene to Recent). This jump in the northern sector has been ascribed to ancient subduction of an aseismic ridge in the center of the arc causing a rupture in the subduction plate and a displacement of volcanic activity to the West in the early-Miocene ( $20 \mathrm{Ma}$; Bouysse and Westercamp 1990). South of Dominica the two branches merge, creating a single volcanic arc active since the Miocene. The active part of the arc (Saba to Dominica in the north, and Dominica to Grenada in the south) has 12 currently active volcanic centers, the most well-known being Soufrière (Guadeloupe), Montagne Pelée (Martinique), Soufrière Hills (Montserrat) and Soufrière (Saint-Vincent). In the last 300 years, these centers have produced several historic effusive and explosive eruptions spanning a broad range of styles and chemistries. Recent activity of the arc $(<2.0 \mathrm{My})$ shows an important segmentation (Macdonald et al. 2000). Three segments can be defined: Saba-Montserrat, Guadeloupe-Martinique and St Lucia-Grenada (Sigurdsson and Carey 1981; Wadge and Shepherd 1984). The segmentation is also manifested in terms of magma production rate. Over the last $0.1 \mathrm{Ma}$, the central segment is characterized by the largest magma production rate, with Dominica reaching a peak at $\sim 40 \mathrm{~km}^{3}$ and Martinique and Guadeloupe at $\sim 8 \mathrm{~km}^{3}$ (Wadge 1984). The north and south segments of the arc have produced significant smaller volumes of about $0-5 \mathrm{~km}^{3}$ over the same time period (Macdonald et al. 2000; Wadge 1984).

Dominica is the only island in the Lesser Antilles arc that exhibits multiple active volcanic centers. From North to South these are: Morne aux Diables (MAD), Morne Diablotins (MD), Morne Trois-Pitons-Micotrin (MTPM), and Morne Plat Pays (also referred to as Plat Pays Volcanic Complex, PPVC). South of Morne Trois-Pitons-Micotrin numerous satellite volcanic centers exist, including Grand Soufrière Hills, Morne Anglais and Foundland. Dominica has produced several $\mathrm{km}^{3}$ of volcanic products since the Pleistocene (Sigurdsson 1972; Lindsay et al. 2005; Smith et al. 2013; Howe et al. 2014, 2015; Boudon et al. 2017).

Recent studies have identified several voluminous pumiceous eruptions, including three large eruptions, expelled from the two central active centers: Layou $(51 \mathrm{ka})$ from Morne Diablotins (MD), and Roseau (33 ka) and Grand Fond (24 ka) from Morne Trois Pitons-Micotrin (MTPM), each involving 3-5 $\mathrm{km}^{3}$ of magma (Boudon et al. 2017). Studies of eruptive deposits (Wadge 1984; Lindsay et al. 2005; Boudon et al. 2017) have demonstrated that eruption volumes of the central part of Dominica are one order of magnitude larger than those from the volcanoes on neighbouring islands (Montagne Pelée, Martinique or Soufrière of Guadeloupe). In the most recent period $(<20 \mathrm{ka})$, at least six Plinian eruptions have been described originating from Morne Diablotins and Morne Trois Pitons-Micotrin (Boudon et al. 2017).

Morne aux Diables volcano (MAD) forms the northern tip of Dominica. Morne aux Diables is composed of one 


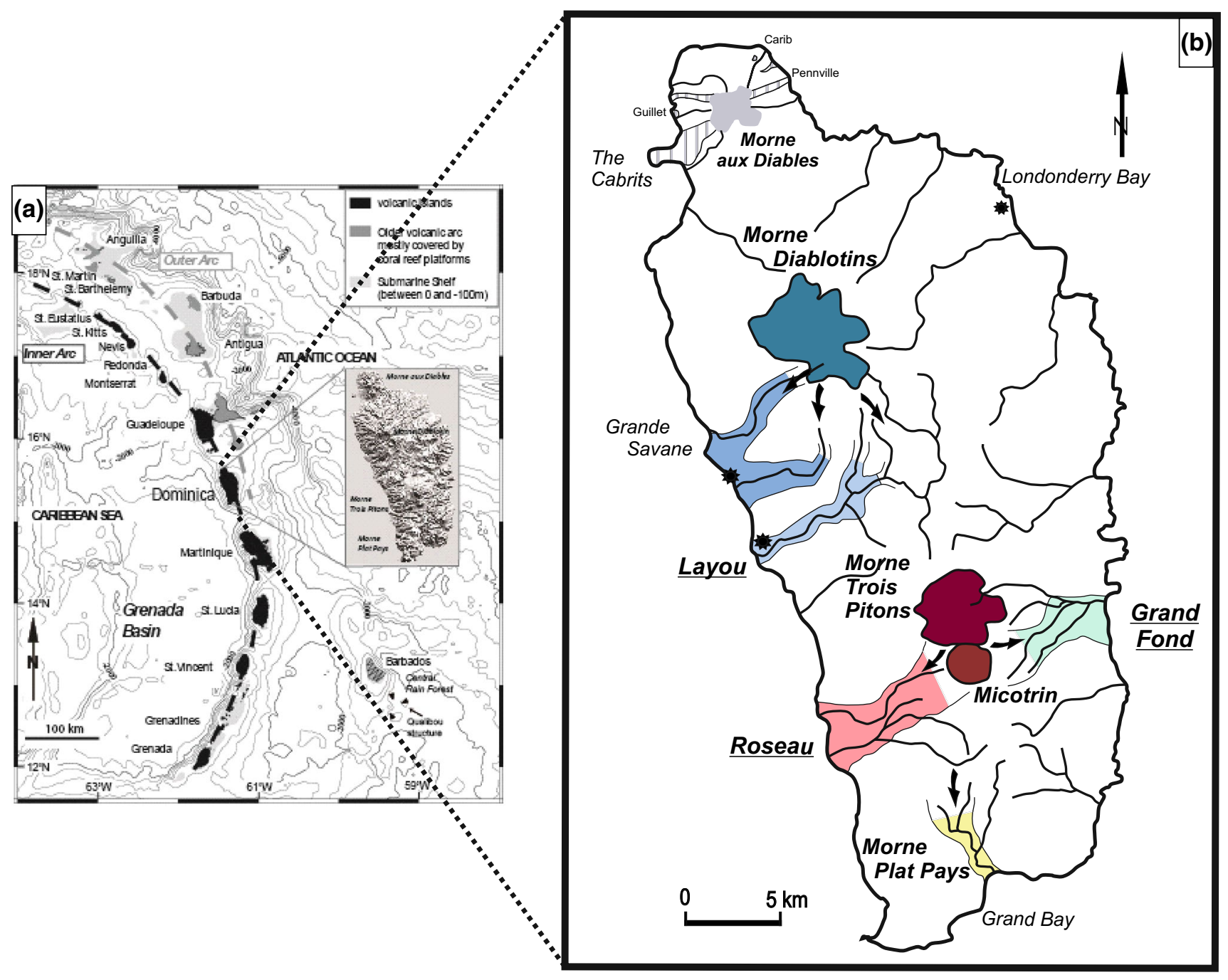

Fig. 1 Geological context of Dominica (Lesser Antilles). a The Lesser Antilles arc. b Main volcanic centers from North (Morne aux Diables) to South (Morne Plat Pays), through the central part with emphasis on the large pumiceous eruptions (Layou, Roseau, Grand Fond; modified from Boudon et al. 2017)

periods of such increased seismic activity occurred in 2000, 1893 and 1841.

Morne Plat Pays or Plat Pays Volcanic Complex (PPVC) is located in the southwestern corner of Dominica. The stratigraphic framework of Plat Pays Volcanic Complex shows a wide range eruptive styles but, as for Morne aux Diables, dome-forming activity dominates. Published work on Plat Pays Volcanic Complex has focussed on volcanic history and chronostratigraphy (Lindsay et al. 2003, 2005; Le Friant et al. 2002; Samper et al. 2008) and on petrology and geochemistry (Halama et al. 2006; Gurenko et al. 2005; Lindsay et al. 2005). A number of lava domes generated abundant block-and-ash pyroclastic density currents. The last of these, Morne Patate lava dome, is dated at $450 \pm 90$ year BP (Roobol et al. 1983). Several flank collapses have occurred, generating voluminous debris volcano, the most recent being in 2003 and 2009. Other 
avalanche deposits that flowed into the Caribbean Sea (Le Friant et al. 2002; Boudon et al. 2007).

\section{Material}

\section{Deposit characteristics and magma composition}

\section{Morne Diablotins and Morne Trois Pitons-Micotrin}

The MI-bearing phenocrysts studied here were selected through detailed sampling of the fallout deposit of the three major pumiceous eruptions (Fig. 2): Layou, Roseau and Grand Fond. All three eruptions involved a plinian phase that generated pumice fallout deposits followed by voluminous ash-and-pumice pyroclastic density currents that filled the valleys and flowed into the sea generating turbidite currents. In the upper parts of the valleys, where the deposits are thickest (up to $100 \mathrm{~m}$ ), they are welded. For each ignimbritic eruption, a volume of $3-5 \mathrm{~km}^{3}$ DRE has been estimated based on stratigraphical investigations. These eruptions involved magmas that follow the andesite-dacite domain for whole rocks (Fig. 3a; Boudon et al. 2017). The magmas at the start of the Morne Diablotins (Layou) and Morne Trois Pitons-Micotrin (Roseau and Grand Fond) pumiceous eruptions are at the limit between acid andesite and dacite and the residual glasses are rhyolitic. These magmas are highly porphyritic (up to 35\%), with phenocrysts of plagioclase, orthopyroxene, amphibole (principally in Layou), oxides and a few clinopyroxenes. Sparse quartz crystals are observed in Layou magmas. The composition of the different mineral phases is as follow: Layou pumices contain plagioclase (rim $\left.\mathrm{An}_{50}\right)$, orthopyroxene $\left(\mathrm{En}_{52}\right)$, amphibole $(\mathrm{Mg} \# 0.55)$, magnetite $\left(\mathrm{Mag}_{73}\right)$, ilmenite $\left(\mathrm{Ilm}_{85}\right)$, clinopyroxene $\left(\mathrm{Wo}_{45}\right)$ and some quartz; Roseau pumices contain plagioclase (rim $\left.\mathrm{An}_{52}\right)$, orthopyroxene $\left(\mathrm{En}_{53}\right)$, amphibole (Mg\#0.56), magnetite $\left(\mathrm{Mag}_{73}\right)$, ilmenite $\left(\mathrm{Ilm}_{86}\right)$, clinopyroxene $\left(\mathrm{Wo}_{44}\right)$; Grand Fond pumice clasts have plagioclase $\left(\operatorname{rim} \mathrm{An}_{52}\right)$, orthopyroxene $\left(\mathrm{En}_{54}\right)$, magnetite $\left(\mathrm{Mag}_{71}\right)$, ilmenite $\left(\mathrm{Ilm}_{85}\right)$. The magma temperature has been determined by $\mathrm{Fe}-\mathrm{Ti}$ oxide thermometry (Ghiorso and Evans 2008) on touching magnetite-ilmenite pairs for Grand Fond $\left(856-860{ }^{\circ} \mathrm{C}\right)$ and using MI-Opx thermometry $\left(879 \pm 25^{\circ} \mathrm{C}\right.$; Putirka 2008 , Eq. 28b). Only MI-Opx pairs were used to constrain temperatures for Roseau and Layou at $887 \pm 25{ }^{\circ} \mathrm{C}$ and $852 \pm 25^{\circ} \mathrm{C}$, respectively. Further details of the revised stratigraphy, sampling and eruption characteristics (ages, deposit volumes, compositions etc) are given in Boudon et al. (2017).

\section{Morne aux Diables}

The Morne aux Diables complex at the north end of Dominica comprises several Upper Pleistocene to Holocene andesitic lava domes emplaced into a sequence of pyroclastic deposits associated with the deeply eroded, 2.0-1.7 Ma proto- Morne aux Diables stratovolcano (Smith et al. 2013; Howe et al. 2015). Block-and-ash pyroclastic density currents are associated with some lava domes. MI-bearing phenocrysts were studied from four selected pumices, whose compositions are representative of this volcanic center (andesite-dacite; Fig. 3a), and one mafic enclave. Two of the five samples (DC 25 and DC 06) are pumice clasts from cross-bedded pyroclastic surge deposits collected in river valleys near Guillet $\left(15^{\circ} 36^{\prime} 28.7^{\prime \prime} \mathrm{N} 61^{\circ} 27^{\prime} 50.1^{\prime \prime} \mathrm{W}\right)$ and on the road to Carib Point ( $\left.15^{\circ} 37^{\prime} 57.6^{\prime \prime} \mathrm{N} 61^{\circ} 25^{\prime} 27.5^{\prime \prime} \mathrm{W}\right)$, respectively. The deposits at Guillet are those shown in Fig. 31 of Smith et al. (2013) who ascribe them to the protoMorne aux Diables stratovolcano. The characteristics of the deposits at both locations suggest that they represent the same eruptive event. In contrast, DC08 and DC139 are vesiculated pyroclasts from block-and-ash pyroclastic density currents at Guillet $\left(15^{\circ} 36^{\prime} 19.8^{\prime \prime} \mathrm{N} 61^{\circ} 27^{\prime} 43.4^{\prime \prime} \mathrm{W}\right)$ and Penneville $\left(15^{\circ} 37^{\prime} 16.9^{\prime \prime} \mathrm{N} 61^{\circ} 24^{\prime} 59.3^{\prime \prime} \mathrm{W}\right)$, respectively, associated with collapse of Morne aux Diable domes. The block-and-ash pyroclastic density current at Guillet has been radiocarbon dates at $43.7 \pm 1.6 \mathrm{kyr}$ by Smith et al. (2013). Finally, DC02 is a quenched microgranular enclave from a block-and-ash pyroclastic density current near East Cabrits $\left(15^{\circ} 35^{\prime} 03.2^{\prime \prime} \mathrm{N} 61^{\circ} 28^{\prime} 09.8^{\prime \prime} \mathrm{W}\right)$, a dome associated with the western flanks of the proto- Morne aux Diables stratovolcano.

Samples DC06, 08, 25 and 139 are silicic andesites (see SI1) containing phenocrysts of orthopyroxene, clinopyroxene and zoned plagioclase. DC08 also contains sparse amphibole phenocrysts with very thin reaction rims. DC06 and DC0 8 contain rare quartz. Andesite enclave DC02 consists of phenocrysts and glomerocrysts of orthopyroxene, clinopyroxene, plagioclase and $\mathrm{Fe}-\mathrm{Ti}$ oxides set in a finegrained matrix. Thermometry (Ghiorso and Evans 2008) of touching ilmenite-magnetite phenocrysts rims from DC02 yields $843-851{ }^{\circ} \mathrm{C}$ and $\mathrm{NNO}+0.45 \log$ units. Touching oxide pairs in glomerocrysts yield consistently higher temperatures $\left(882-963{ }^{\circ} \mathrm{C}\right)$ at similar $f \mathrm{O}_{2}(\mathrm{NNO}+0.30$ to 0.35$)$. These higher temperatures may reflect magmatic conditions in the andesite magma prior to mixing with the host magma.

\section{Plat Pays Volcanic Complex}

A selection of mafic samples from Dominica was collected (see SI2). We focus on scoriaceous deposits, possibly originating from Plat Pays Volcanic Complex, that represent the potential basic endmember composition of Dominica's magmas (hereafter referred as the mafic samples). We studied two decimetre-thick scoria fallout deposits at Fond Baron Estate $\left(15^{\circ} 16^{\prime} 26^{\prime \prime} \mathrm{N}, 61^{\circ} 21^{\prime} 31^{\prime \prime} \mathrm{W}\right)$ and La Sorcière-Soufrière $\left(15^{\circ} 14^{\prime} 01^{\prime \prime} \mathrm{N}, 61^{\circ} 21^{\prime} 46^{\prime \prime} \mathrm{W}\right)$. Both sites display similar 

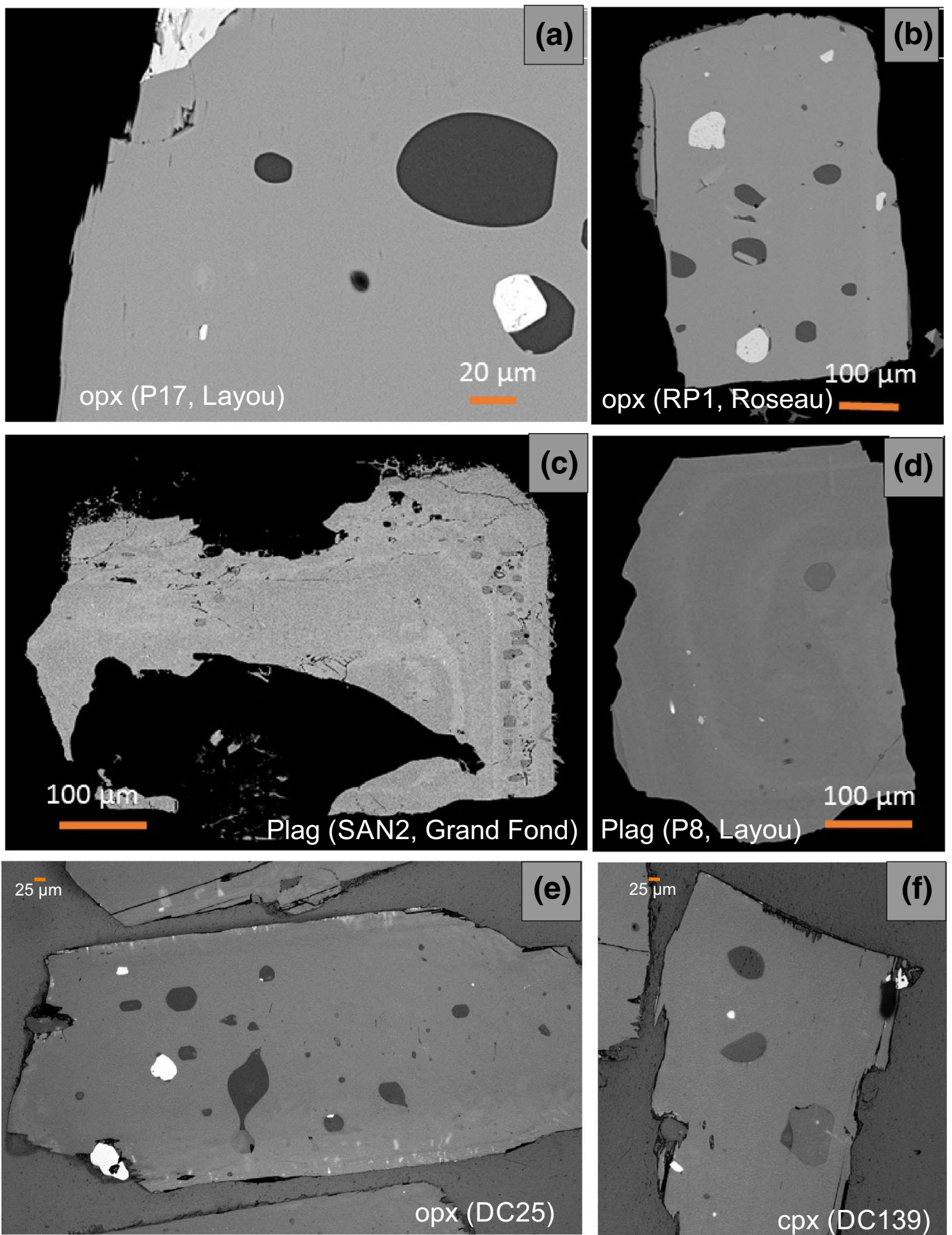

Fig. 2 SEM/optical images of MIs in Opx, Cpx and Fd. a Orthopyroxene from Layou (SEM); b Orthopyroxene from Roseau (SEM); c Plagioclase from Grand Fond (SEM); d Plagioclase from Layou
(SEM); e Orthopyroxene from DC25 sample from Morne aux Diables (reflected light); f Clinopyroxene from DC139 sample from Morne aux Diables (reflected light) 


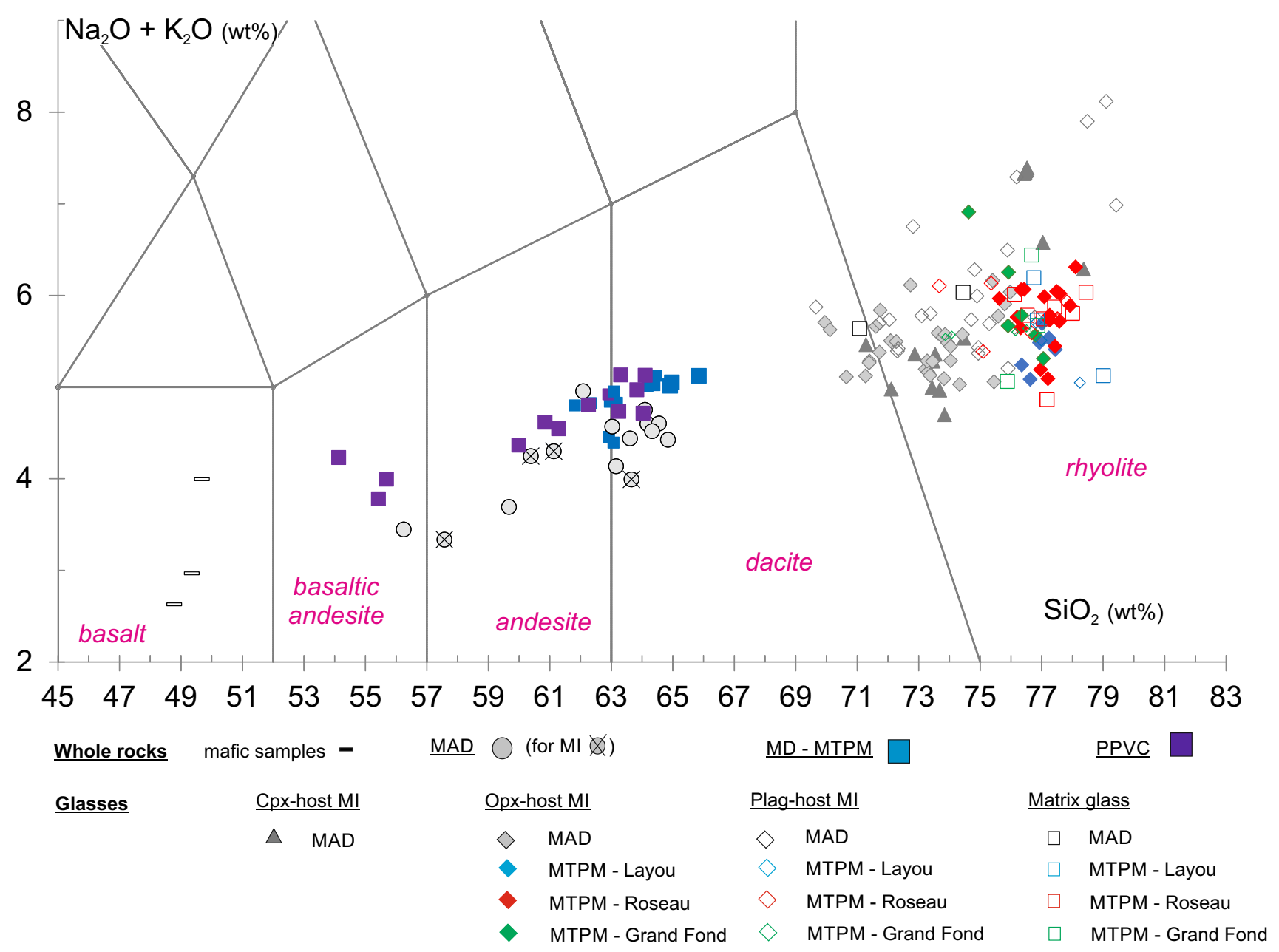

Fig. 3 Compositions of melt inclusions compared to whole rocks (LeBas et al. 1986). a TAS diagram: grey dots: scorias from Plat Pays Volcanic Complex (see Supplementary Material SI1); blue squares: whole rock from Morne Diablotins-Morne Trois PitonsMicotrin (Boudon et al. 2017); purple squares: whole rocks from Plat

characteristics. Scoria clasts, up to a few $\mathrm{cm}$ in diameter, are basaltic with low phenocryst content (mainly plagioclase). Only whole rock chemistry of these samples is reported here.

\section{Samples: melt inclusion host and preparation}

\section{Morne Diablotins and Morne Trois Pitons-Micotrin}

For each eruption from Morne Diablotins and Morne Trois Pitons-Micotrin, the density distribution of the first eruptive unit for each Plinian fallout deposit was obtained from a population of at least 100 pumice clasts identified and sieved at $16-32 \mathrm{~mm}$. Depending on the density distribution, six to ten pumice clasts were collected from the density mode (Gaussian distribution) to ensure that the pumice clasts are representative. Clasts were gently
Pays Volcanic Complex (Gurenko et al. 2005). Grey circles: Morne aux Diables whole rock; data with black cross within grey circle correspond to whole rocks from which host minerals of MIs were extracted. b Details of MI compositions. See diagram for legend. Matrix glasses are shown for comparison

crushed to powder, then sieved in different size fractions, the largest of which $(0.315-0.500 \mathrm{~mm}, 0.500-0.750 \mathrm{~mm}$ and $0.750-1 \mathrm{~mm}$ ) were recovered for crystal handpicking under a binocular microscope. Orthopyroxene (Opx) and plagioclase (Pl) crystals from each eruption of Morne Diablotins and Morne Trois Pitons-Micotrin were then mounted in epoxy resin and polished to $0.3 \mu \mathrm{m}$.

\section{Morne aux Diables}

Clasts were lightly crushed and handpicked for phenocrysts. Separated orthopyroxene (Opx), clinopyroxene $(\mathrm{Cpx})$, plagioclase $(\mathrm{Pl})$ crystals were mounted in epoxy resin and polished to $0.3 \mu \mathrm{m}$. 


\section{Results}

\section{Melt inclusion host minerals}

A total of 113 melt inclusions were analysed across all three volcanic centers Morne Diablotins and Morne Trois PitonsMicotrin (43) and Morne aux Diables (70) (Table 1). Details of host mineral compositions are provided in SI4.

\section{Morne Diablotins and Morne Trois Pitons-Micotrin}

Opx and Pl phenocrysts from Layou, Roseau and Grand Fond were mounted separately. As Pl-hosted melt inclusions were consistently scarcer and smaller, we obtained more numerous data for Opx than $\mathrm{Pl}$. Opx and $\mathrm{Pl}$ composition ranges between $\operatorname{En}_{49-56}(n=7)$ and $\mathrm{An}_{52-53}(n=3)$ (Layou), $\mathrm{En}_{50-53}(n=13)$ and $\mathrm{An}_{46-60}(n=6)$ (Roseau), and $\mathrm{En}_{52-55}$ $(n=6)$ and $\mathrm{An}_{49-59}(n=6)$ (Grand Fond). In Opx, MI are ubiquitous from core to rim with sizes from a few $\mu \mathrm{m}$ up to more than $50 \mu \mathrm{m}$ (Fig. 2a, b). Analyzed MI were glassy with no evidence of rim crystallization in SEM images. In plagioclase, scarce MI are smaller than $40 \mu \mathrm{m}$. In strongly zoned plagioclase MIs form a sieve-texture ring of numerous small inclusions parallel to the zoning (Fig. 2c), whereas in unzoned plagioclase they have a random distribution (Fig. 2d). These textural characteristics are similar in all three eruptions.

\section{Morne aux Diables}

Opx, $\mathrm{Pl}$ and Cpx were mounted separately (Fig. 2e, f). Host mineral composition are as follows: DC25 Opx- $\mathrm{En}_{49-54}$ $(n=10), \mathrm{Pl}-\mathrm{An}_{55-74}(n=5)$ and $\mathrm{Cpx}-\mathrm{Wo}_{41-42}(n=11)$; DC06 $\mathrm{En}_{58-62}(n=6)$ and $\mathrm{An}_{60-87}(n=4) ;$ DC08 $\mathrm{En}_{53-57}$ $(n=4)$ and $\mathrm{An}_{55-73}(n=7) ; \mathrm{DC} 139 \mathrm{En}_{54-62}(n=12), \mathrm{An}_{66-79}$ $(n=3)$ and $\mathrm{Wo}_{41-43}(n=3) ; \mathrm{DC} 02 \mathrm{An}_{55-89}(n=4)$ and $\mathrm{Wo}_{43}$ $(n=2)$.

\section{Melt inclusion glass compositions}

\section{Major elements}

Melt inclusions from the three studied Morne Diablotins and Morne Trois Pitons-Micotrin eruptions are rhyolitic in composition regardless of their host crystal (TAS classification, Fig. 3a, b), with variations in $\mathrm{Na}_{2} \mathrm{O}+\mathrm{K}_{2} \mathrm{O}$ from 4.9 to $6.5 \mathrm{wt} \%$ (anhydrous) and $\mathrm{SiO}_{2}$ content of 75.6-79 wt\% for Opx, and variations in $\mathrm{Na}_{2} \mathrm{O}+\mathrm{K}_{2} \mathrm{O}$ of $5.0-5.6 \mathrm{wt} \%$ for a $\mathrm{SiO}_{2}$ range of 76.1 to $78.2 \mathrm{wt} \%$ for Pl. MIs plot in the calc-alkaline field, as defined by the $\mathrm{SiO}_{2}$ vs. $\mathrm{K}_{2} \mathrm{O}$ content (Fig. 4a), with $\mathrm{Al}_{2} \mathrm{O}_{3}$ contents between 11 and $15 \mathrm{wt} \%$
(Fig. 4b) and low $\mathrm{CaO}$ content, between 1 and $2.5 \mathrm{wt} \%$ (Fig. 4c). There is no textural evidence for post-entrapment crystallization of the host mineral (Fig. 2). Pl- and Opxhosted MI evidence some differences in composition for certain elements, i.e. Opx-hosted MI tend to be richer in $\mathrm{Fe}$ and $\mathrm{Mg}$ than those hosted in Pl (Fig. 4d).

Melt inclusions from Morne aux Diables are almost all rhyolitic, although some lie at the border with dacite (Fig. 3a). They describe a differentiation trend spanning a large $\mathrm{SiO}_{2}$ range between 70 and 79.5 wt\% (Figs. 3b, 4). The trend is clear for $\mathrm{CaO}, \mathrm{FeO}, \mathrm{K}_{2} \mathrm{O}$ or $\mathrm{Al}_{2} \mathrm{O}_{3}$ (Fig. 4). The Morne Diablotins and Morne Trois Pitons-Micotrin MIs described above lie at the most differentiated end of this trend (Fig. 4).

\section{Trace elements}

Trace elements analyses of MIs from the Morne Diablotins and Morne Trois Pitons-Micotrin volcanic centers are discussed by element groups for each eruption (Fig. 5) and compared to whole rock compositions for Morne Diablotins, Morne Trois Pitons-Micotrin and Morne aux Diables.

1. High Field Strength Elements (HFSE: U, Th): There is a strong positive correlation between the HFSE for MIs, whole rock, matrix glass, mafic samples and crystals as shown by U-Th (Fig. 5a). All eruptions describe the same linear correlation passing through the origin, independent of the MI host. However Grand Fond tends to sit at the lower end of this correlation $(\mathrm{Th}=8.3-10.6 \mathrm{ppm})$ with respect to Roseau and Layou, which display the most differentiated melt ( $\mathrm{Th}=8-12.7$ and 9.9-11.7 ppm, respectively). Compared to whole rock compositions of Morne Diablotins, Morne Trois Pitons-Micotrin and Morne aux Diables, MIs lie at the silica-rich end of this differentiation trend, which is common to all three eruptive centers. A striking feature of this plot is the tendency of MIs to be more differentiated in terms of trace elements (higher $\mathrm{U}, \mathrm{Th}$ ) than the matrix glasses, although the major element chemistry is quite similar (Fig. 4). The same feature has been observed previously at a number of volcanoes, e.g. Ruapehu, New Zealand (Kilgour et al. 2013) or Uturuncu, Bolivia (Muir et al. 2014), where it is attributed to protracted crystallization within a crystal mush prior to eruption.

2. Large Ion Lithophile Elements (LILE) $\mathrm{Rb}, \mathrm{K}, \mathrm{Sr}$ and Ba: The $\mathrm{Sr}-\mathrm{K}_{2} \mathrm{O}$ plot (Fig. 5b) illustrates the compatible behavior of $\mathrm{Sr}$, consistent with Pl-dominated fractionation. Conversely, Ba-Th (Fig. 5c) shows a good correlation, albeit with slight differences between Opx and Pl MI composition, reflecting a lack of biotite and alkali feldspars in the crystallizing assemblage in any significant proportion. Once again, all eruptions, including 


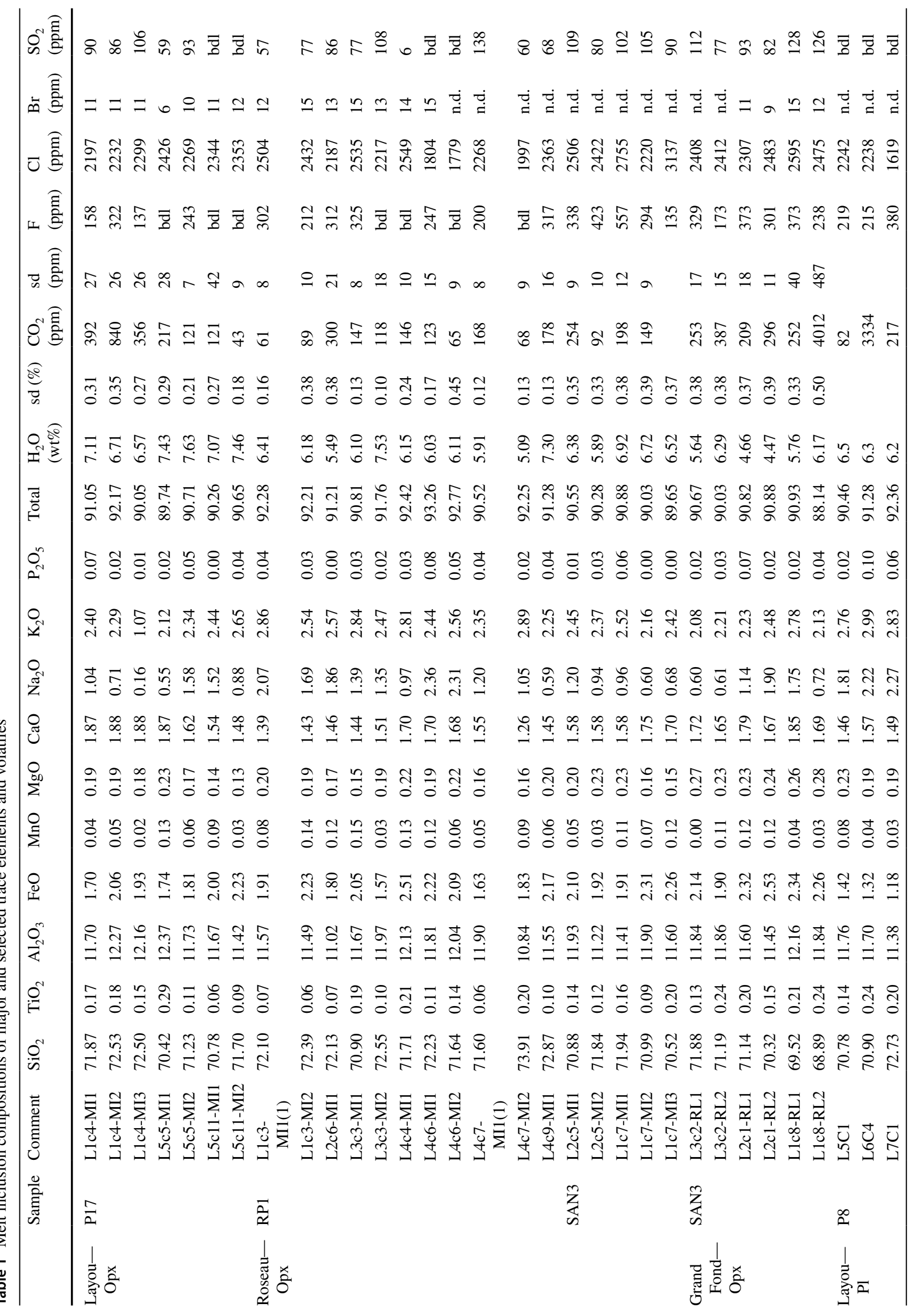




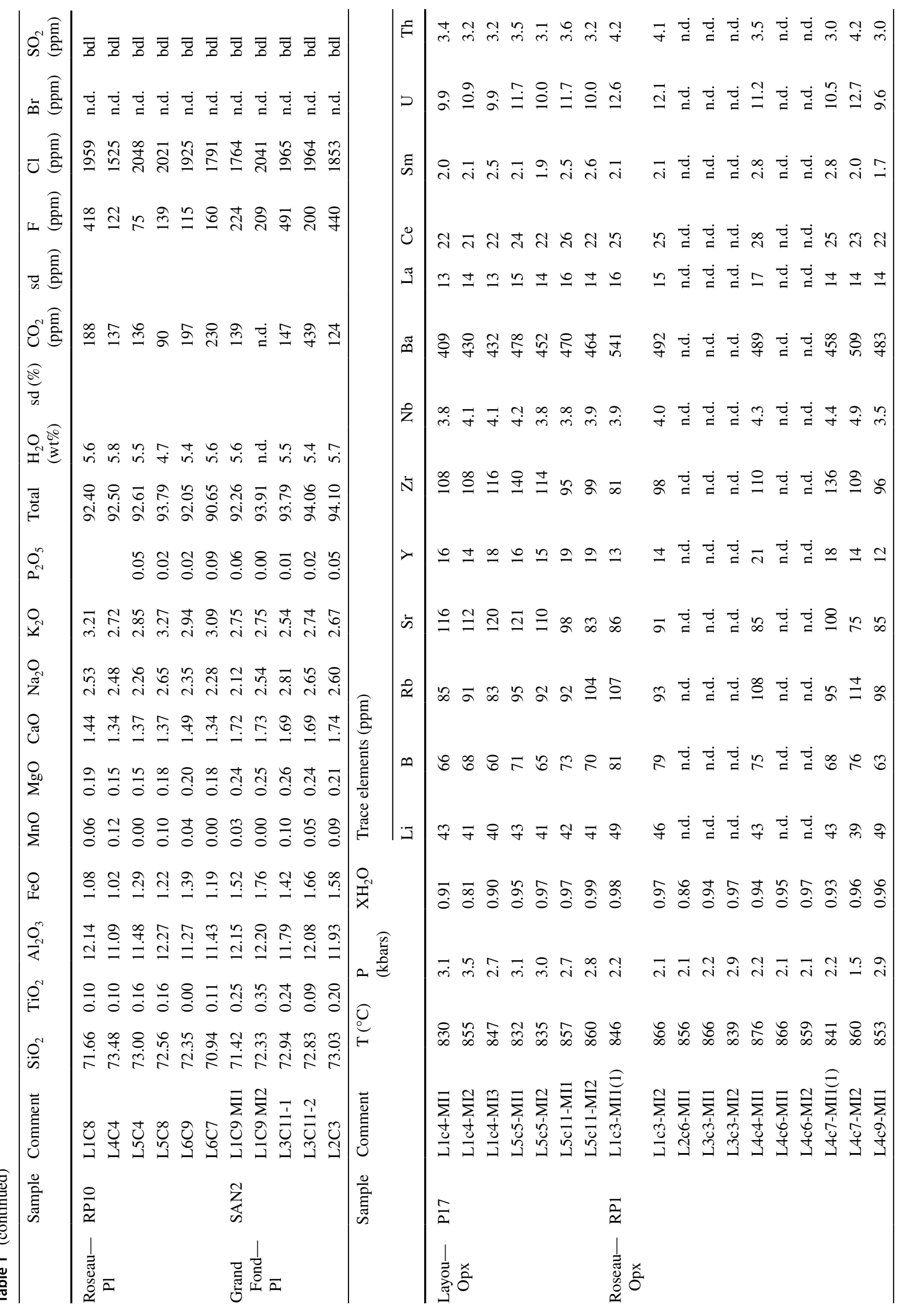




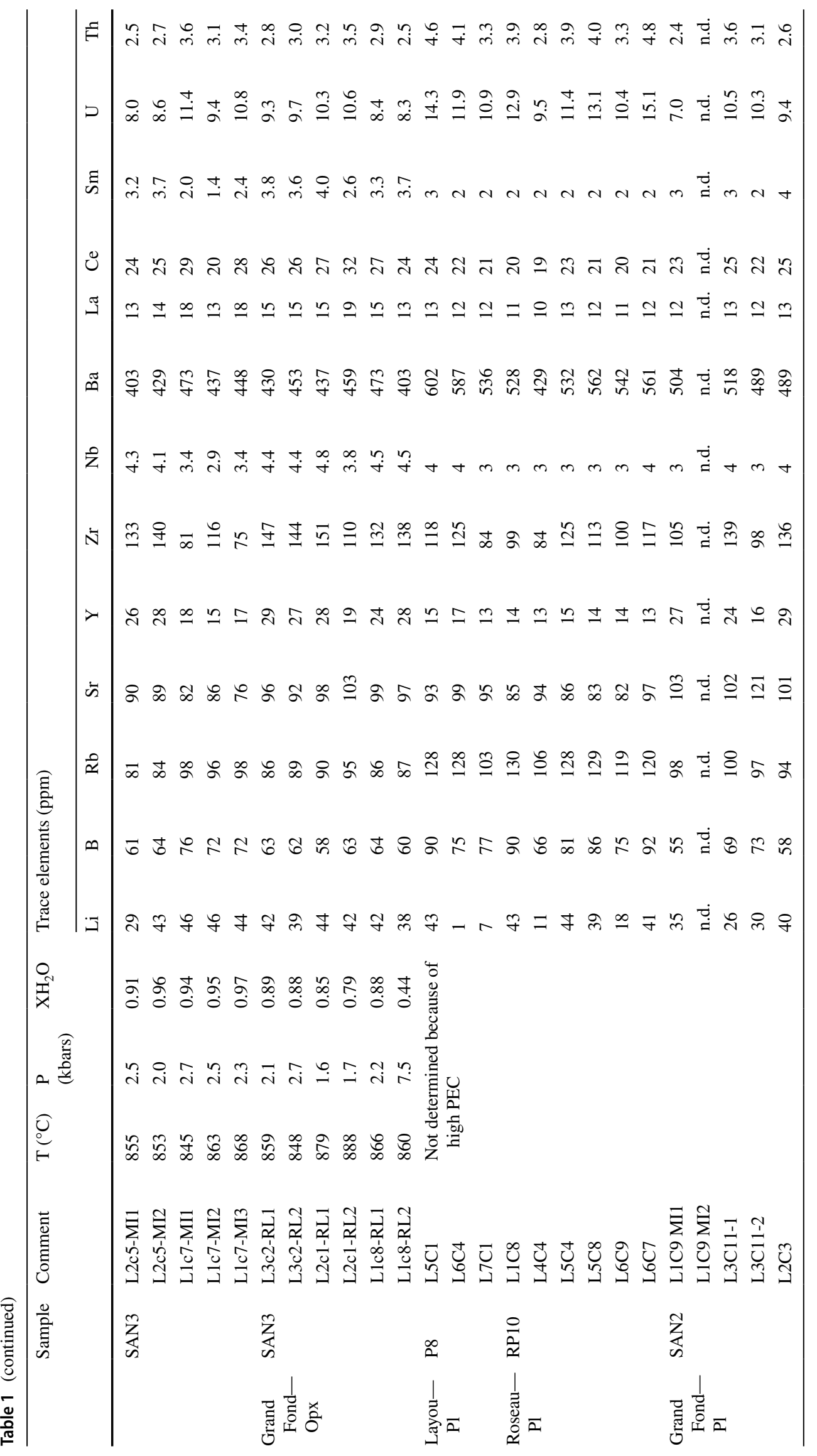


Morne aux Diables, describe on the same relationship and MIs are more evolved than matrix glasses.

3. LILE and REE vs. HFSE systematics: The Rb vs. $\mathrm{Zr}$ diagram (Fig. 5d) illustrates first the three correlations identified for each Morne Diablotins and Morne Trois Pitons-Micotrin eruption using whole rock and matrix glass composition (Boudon et al. 2017). MIs from Grand Fond plot in the same domain as the matrix glass. The compositional domain covered by Grand Fond MIs is less scattered than that of Layou and Roseau. These two eruptions have MI compositions that depart from the matrix glass, being $\mathrm{Rb}$-rich and $\mathrm{Zr}$-poor. The tendency for MIs to plot at lower $\mathrm{Zr}$ and at elevated $\mathrm{Rb}$ is indicative of zircon saturation at advanced stages of crystallization that are recorded by MIs, but not matrix glass. That zircon saturation is confined to evolved MIs, but not matrix glasses is consistent with derivation of phenocrysts from a cool magmatic mush prior to entrainment in hotter magma during eruption. The calculated zircon saturation temperatures are $743-795{ }^{\circ} \mathrm{C}$ (Watson and Harrison 1983). These temperatures are consistent with low melt-fraction, evolved melts, but are almost $100^{\circ} \mathrm{C}$ lower than the calculated Opx-MI and $\mathrm{Fe}$-Ti oxide temperatures presented above $\left(852-877^{\circ} \mathrm{C}\right)$. This temperature difference can be ascribed to heating during magma ascent and crystallization via latent heat release (Blundy et al. 2006) or entrainment of crystals from mush by a hotter carrier melt (Kilgour et al. 2014).

4. $\mathrm{Li}$ and $\mathrm{B}$ trace elements: The $\mathrm{B}-\mathrm{K}_{2} \mathrm{O}$ diagram (Fig. 6a) illustrates a common signature for Opx-hosted MIs from all eruptions, with Grand Fond MIs describing the lower end of this relationship and Roseau the upper end. Plhosted MIs show roughly the same relationship, slightly extended towards higher values of $\mathrm{B}$. Boron and $\mathrm{Li}$ show some relationship with each other for MIs in Opx (Fig. 6b); for Pl the data are displaced to slightly higher $\mathrm{Li}$ over a greater range in $\mathrm{B}$, but with little evidence for any relationship. The signature in $\mathrm{Li}$ is roughly the same for the three eruptions $(43 \pm 5 \mathrm{ppm})$ whatever the $\mathrm{H}_{2} \mathrm{O}$ content (between 4.5 and $7.5 \mathrm{wt} \%$; Fig. 6c), with a slight enrichment for Roseau. For some Pl-hosted MIs, the $\mathrm{Li}$ content decreases from $43 \pm 5 \mathrm{ppm}$ down to zero, without any accompanying $\mathrm{H}_{2} \mathrm{O}$ loss. This may reflect rapid diffusive migration of $\mathrm{Li}$ through the host crystal.

5. Volatile components $\left(\mathrm{H}_{2} \mathrm{O}, \mathrm{CO}_{2}, \mathrm{~F}, \mathrm{Cl}, \mathrm{Br}, \mathrm{S}\right)$.

Volatile contents for Morne Diablotins, Morne Trois Pitons-Micotrin and Morne aux Diables, are presented as histograms in Fig. 7 for $\mathrm{H}_{2} \mathrm{O}$ and $\mathrm{CO}_{2}$ content and Fig. 8 for halogen $(\mathrm{F}, \mathrm{Cl}, \mathrm{Br})$ and $\mathrm{SO}_{2}$ content. Histograms distinguish between MIs hosted in different minerals.
1. Water $\mathrm{H}_{2} \mathrm{O}$ contents of Morne Diablotins and Morne Trois Pitons-Micotrin MI range from 4.5 to $7.6 \mathrm{wt} \%$ (Fig. 7). This entire range is captured in the Opx-hosted MI. The maximum $\mathrm{H}_{2} \mathrm{O}$ is $7.6 \mathrm{wt} \%$ for Layou (range 6.5-7.6 wt\%), $7.5 \mathrm{wt} \%$ for Roseau (5.5-7.5 wt\%), and $6.3 \mathrm{wt} \%$ for Grand Fond (4.5-6.3 wt \%). The maximum $\mathrm{H}_{2} \mathrm{O}$ of Pl-hosted MIs (Fig. 7) is slightly lower than for Px, i.e. 6.5, 5.8 and $5.7 \mathrm{wt} \%$ for Layou, Roseau and Grand Fond, respectively. This may reflect diffusive $\mathrm{H}_{2} \mathrm{O}$-loss through the host crystal or MI-trapping in Px under slightly less $\mathrm{H}_{2} \mathrm{O}$-rich conditions. MIs from Morne aux Diables show the same high $\mathrm{H}_{2} \mathrm{O}$ content of $7.6 \mathrm{wt} \%$, in a Cpx-hosted MI, although the $\mathrm{H}_{2} \mathrm{O}$ spread is larger for Cpx (1.2-7.6 wt\%) than Opx. Opx display a Gaussian distribution of $\mathrm{H}_{2} \mathrm{O}$ content but with a slightly lower maximum value (3.2-6.7 wt\%). Contrary to Morne Diablotins and Morne Trois Pitons-Micotrin, Pl-hosted MIs from Morne aux Diables exhibit comparably high $\mathrm{H}_{2} \mathrm{O}$ content to pyroxene, with the highest value ( $7 \mathrm{wt} \%$ ) lying between the maximum $\mathrm{H}_{2} \mathrm{O}$ content in Cpx and Opx.

2. Carbon dioxide The majority of Morne Diablotins and Morne Trois Pitons-Micotrin $\mathrm{CO}_{2}$ contents lie in the range $50-834 \mathrm{ppm}$. The range in $\mathrm{Pl}$-hosted $\mathrm{MI}$ is lower than that in Opx-hosted MI, with the highest $\mathrm{CO}_{2}$ content being $439 \mathrm{ppm}$ for Grand Fond (Fig. 7). In contrast to $\mathrm{H}_{2} \mathrm{O}$, Grand Fond sits at the higher end of the $\mathrm{CO}_{2}$ range. Two very high $\mathrm{CO}_{2}$ values were measured (offscale in Fig. 7): 3998 ppm in an Opx MI from Grand Fond, $3334 \mathrm{ppm}$ in a Pl MI from Layou. Morne aux Diables MIs in both Px and Pl show a larger range of values than for Morne Diablotins and Morne Trois Pitons-Micotrin. Two Opx-hosted MIs have 1117 and 1239 ppm, and five Cpx-hosted MIs describe a restrictive domain between 1134 and 1149 ppm. In Pl-hosted MIs, high $\mathrm{CO}_{2}$ values are also present: $2455 \mathrm{ppm}$ and $2613 \mathrm{ppm} . \mathrm{CO}_{2}$ shows a broad overall inverse variation with the incompatible element Th (Fig. 9a) consistent with volatile-saturated crystallization conditions (Blundy and Cashman 2008).

Some MIs from Morne Diablotins and Morne Trois Pitons-Micotrin and from Morne aux Diables show high $\mathrm{CO}_{2}$ content $(\leq 4000 \mathrm{ppm})$. Such high values could result from contamination, although the ${ }^{12} \mathrm{C}+$ signal was stable during SIMS analysis, which is consistent with high intrinsic $\mathrm{CO}_{2}$ contents rather than any surficial carbon-rich contamination. Similarly $\mathrm{CO}_{2}$-rich melt inclusions have been described from other silicic arc volcanoes (e.g. Blundy et al. 2010) and have been attributed to fluxing of melts with magmatic $\mathrm{CO}_{2}$-rich fluids by Caricchi et al. (2018). For these reasons, we include the high- $\mathrm{CO}_{2}$ Dominica MIs in our discussion. 


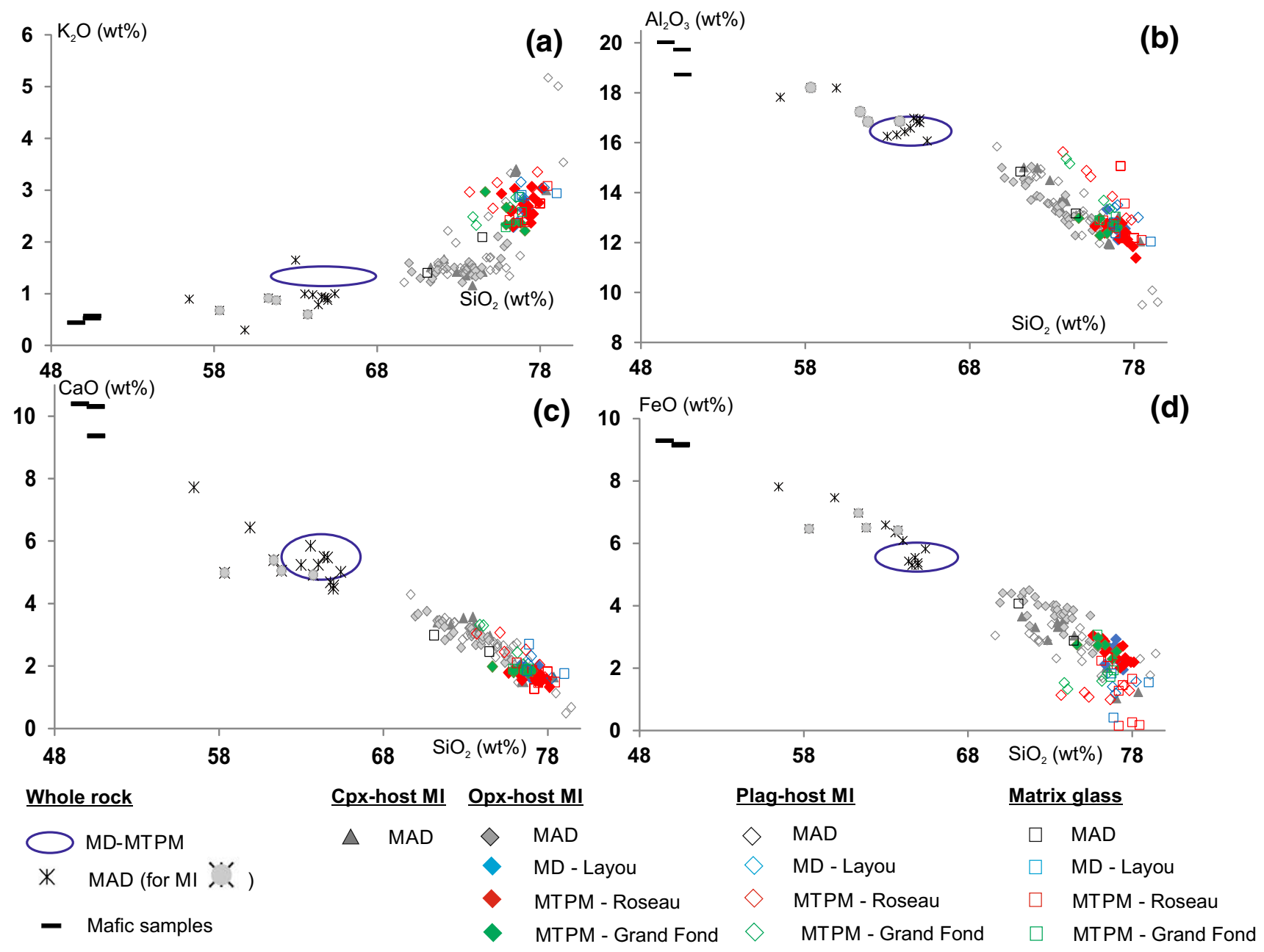

Fig. 4 Selected major element composition of melt inclusions. All data are plotted volatile-free, summed to $100 \%$. a $\mathrm{K}_{2} \mathrm{O}, \mathbf{b ~} \mathrm{Al}_{2} \mathrm{O}_{3}$, c $\mathrm{CaO}$, and $\mathbf{d}$ FeO. Whole rocks (WR) and matrix glasses (MG) from Boudon et al. (2017). Symbols as in Fig. 3

3. Halogens: Fluorine in Morne Diablotins and Morne Trois Pitons-Micotrin MIs ranges between 100 and 600 ppm (Fig. 8). Roseau shows a maximum distribution between 150 and $600 \mathrm{ppm}$. Grand Fond MIs show roughly the same range, whereas those from Layou are shifted towards the F-poor endmember. Like $\mathrm{CO}_{2}$ F shows a negative variation with Th (Fig. 10a), suggestive of partitioning into the fluid phase during crystallisation. Morne aux Diables MIs display the highest F content endmember, with Opx-hosted MI reaching 677 ppm and Pl-hosted MI 798 ppm.

Chlorine contents in Morne Diablotins and Morne Trois Pitons-Micotrin range from 1800 to $3140 \mathrm{ppm}$. The $\mathrm{Cl}$ range within Opx-hosted $\mathrm{MI}$ is generally greater than in $\mathrm{Pl}$ (Fig. 8). For Opx-MI from each eruption, $\mathrm{Cl}$ values fall within a restricted range over a significant range in $\mathrm{Th}$ content, with $2303 \pm 78 \mathrm{ppm}$ for Layou, $2355 \pm 340 \mathrm{ppm}$ for Roseau and $2446 \pm 96$ ppm for Grand Fond (Fig. 10b).
Morne aux Diables MIs span a domain with higher $\mathrm{Cl}$ values than for Morne Diablotins and Morne Trois Pitons-Micotrin: the peak of $\mathrm{Cl}$ within the Gaussian distribution is shifted toward values of $\sim 3000 \mathrm{ppm}$. Pl-hosted MI show the highest $\mathrm{Cl}$ content, up to $4428 \mathrm{ppm}$. These $\mathrm{Cl}$ contents lie at the high end of the values for silicic melts reported by Webster et al. (2018) in their global compilation. Chlorine and fluorine contents are well correlated for the entire dataset (Fig. 10e), although the greater range for $\mathrm{F}$, compared to $\mathrm{Cl}$, suggests that $\mathrm{Cl}$ is more strongly partitioned into the fluid phase during crystallisation.

The plot of $\mathrm{Cl}$ vs. $\mathrm{H}_{2} \mathrm{O}$ (Fig. 11) shows that for Morne Diablotins and Morne Trois Pitons-Micotrin the compositions of Opx-hosted MIs contain variable $\mathrm{H}_{2} \mathrm{O}$ contents (7.6-4.4 wt\%) over a restricted range of $\mathrm{Cl}$ content $(2374 \pm 260 \mathrm{ppm})$. Some Pl-hosted MIs depart from this domain with lower $\mathrm{Cl}$ content (1600-2000 ppm) and $\mathrm{H}_{2} \mathrm{O}$ contents around $6 \mathrm{wt} \%$. The composition of Morne aux 

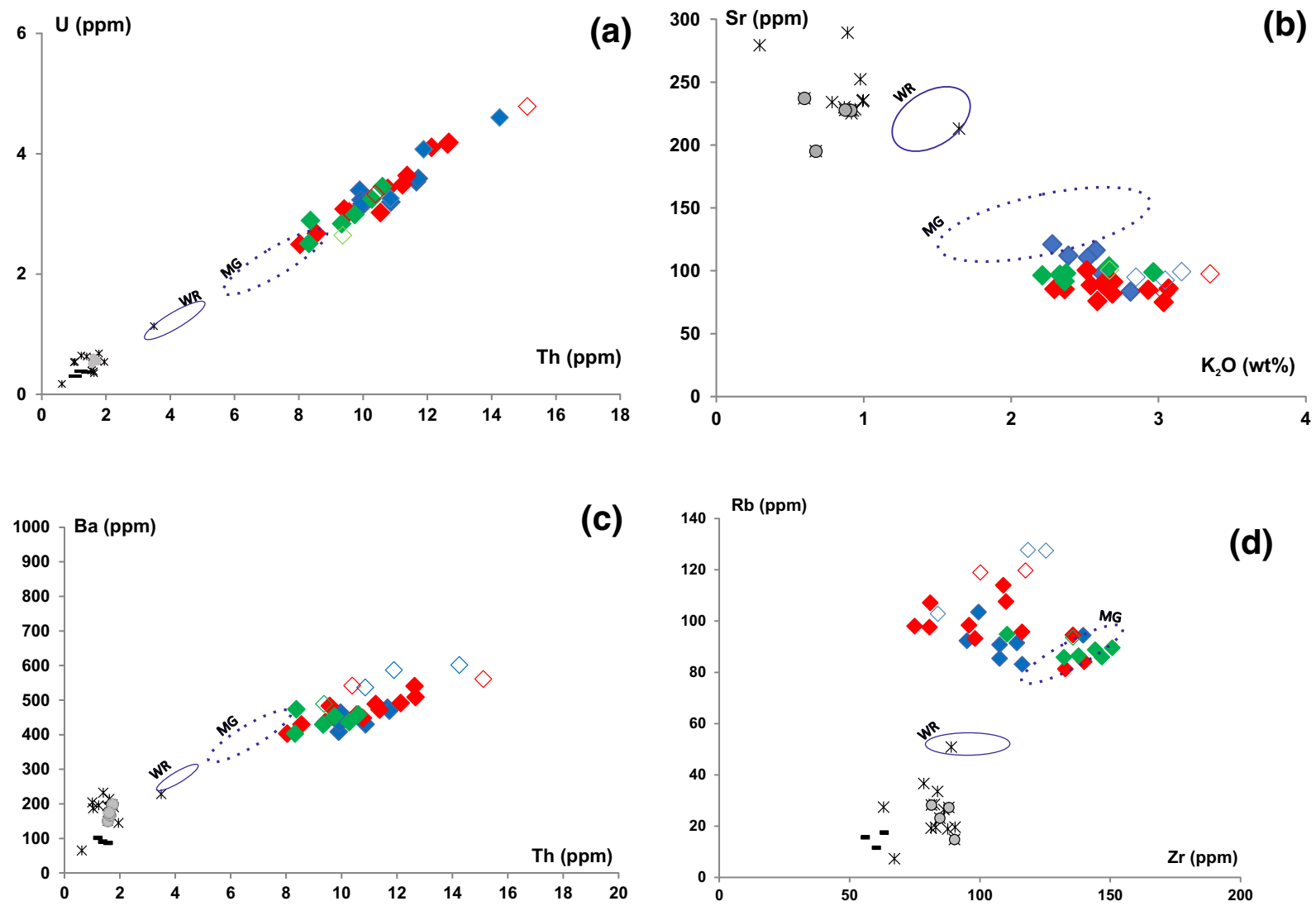

Whole rock

$\begin{array}{llll} & \text { Opx-host MI } & \underline{\text { Plag-host MI }} & \underline{\text { Matrix glass }} \\ \text { * MD-MTPM } & >\text { MD - Layou } & \diamond \text { MD - Layou } & \because \cdots \cdot \text { MTPM - Layou } \\ -\quad \text { Mafic samples } & \diamond \text { MTPM - Roseau } & \diamond \text { MTPM - Roseau } \\ \text { MTPM - Grand Fond } & \diamond \text { MTPM - Grand Fond }\end{array}$

Fig. 5 Selected trace element composition of melt inclusions compared to whole rocks and matrix glasses. a U vs. Th. b $\mathrm{Sr}$ vs. $\mathrm{K}_{2} \mathrm{O}$. c Ba vs. Th. d Rb vs. Zr. Whole rocks (WR—-solid domain) and matrix glasses (MG—dashed domain) from Boudon et al. (2017). Symbols as in Fig. 3

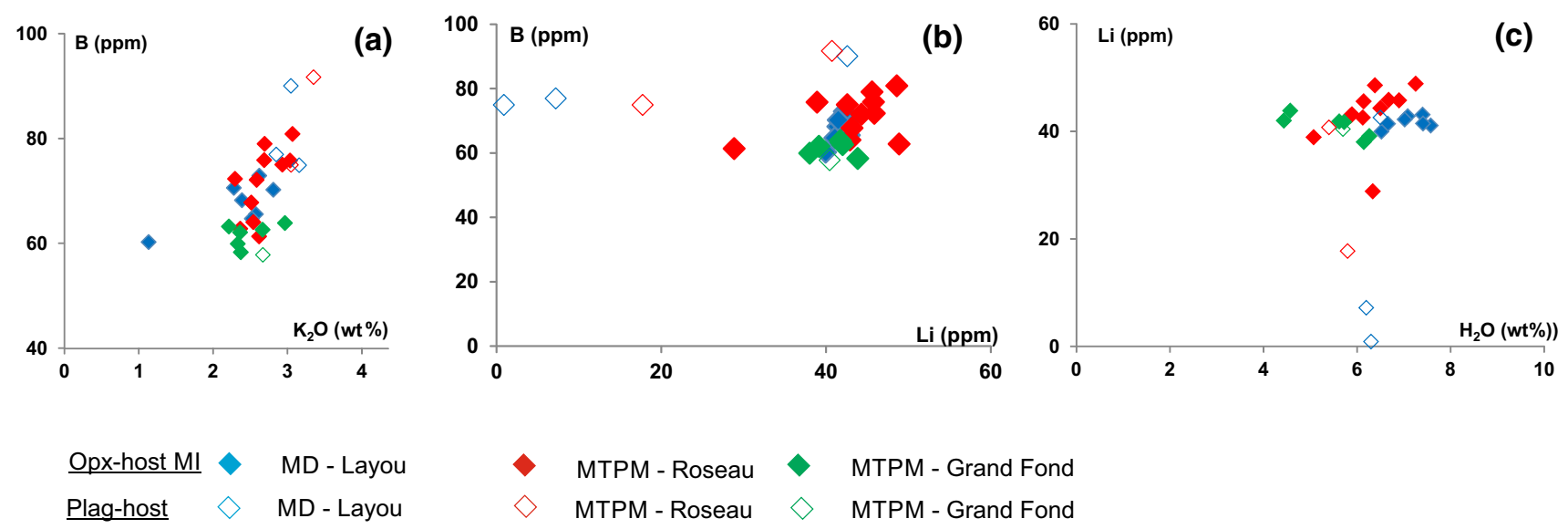

Fig. 6 Light trace element contents of melt inclusions. a B vs. $\mathrm{K}_{2} \mathrm{O}$. b B vs. Li. c Li vs. $\mathrm{H}_{2} \mathrm{O}$. Symbols as in Fig. 3 

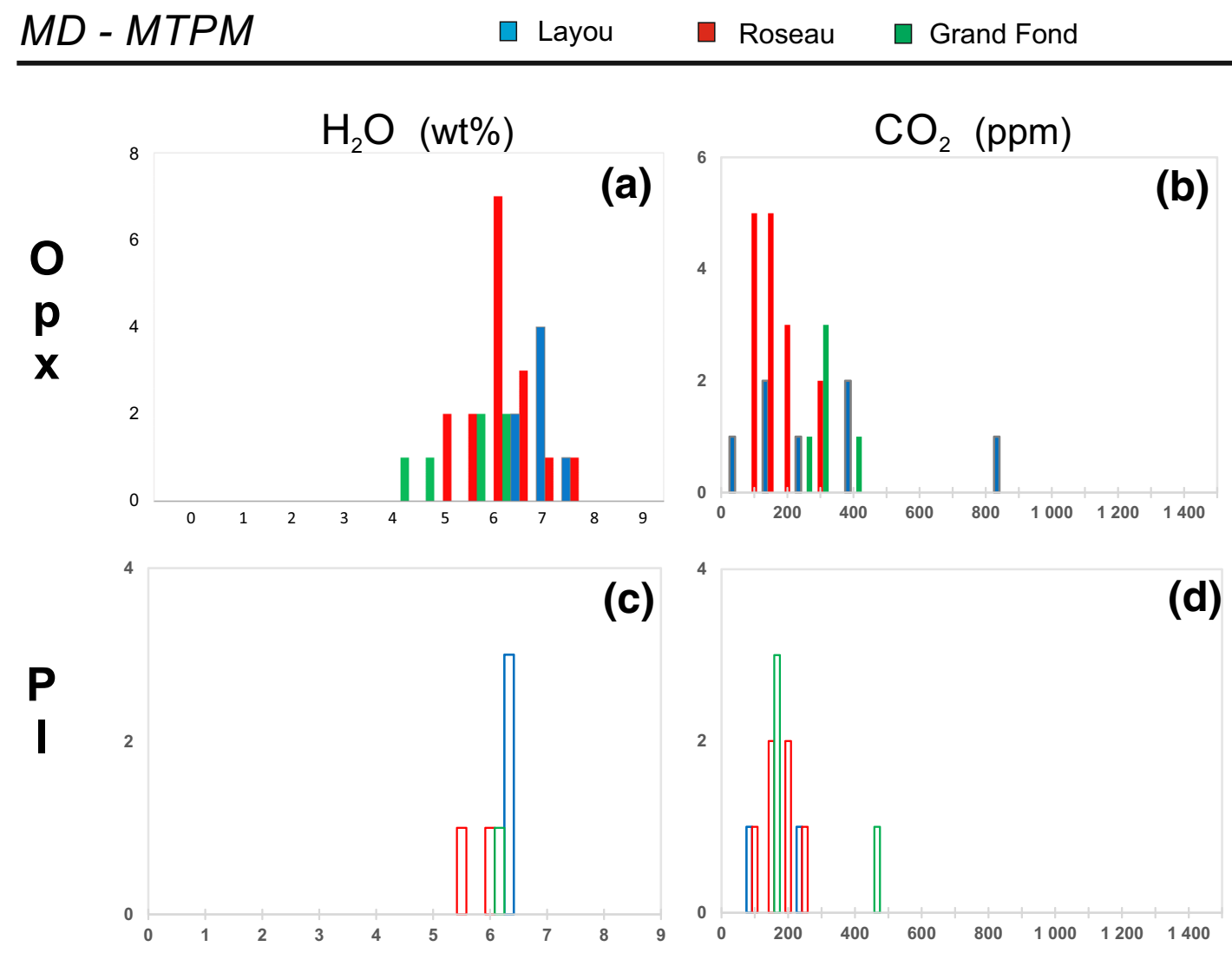

$M A D$

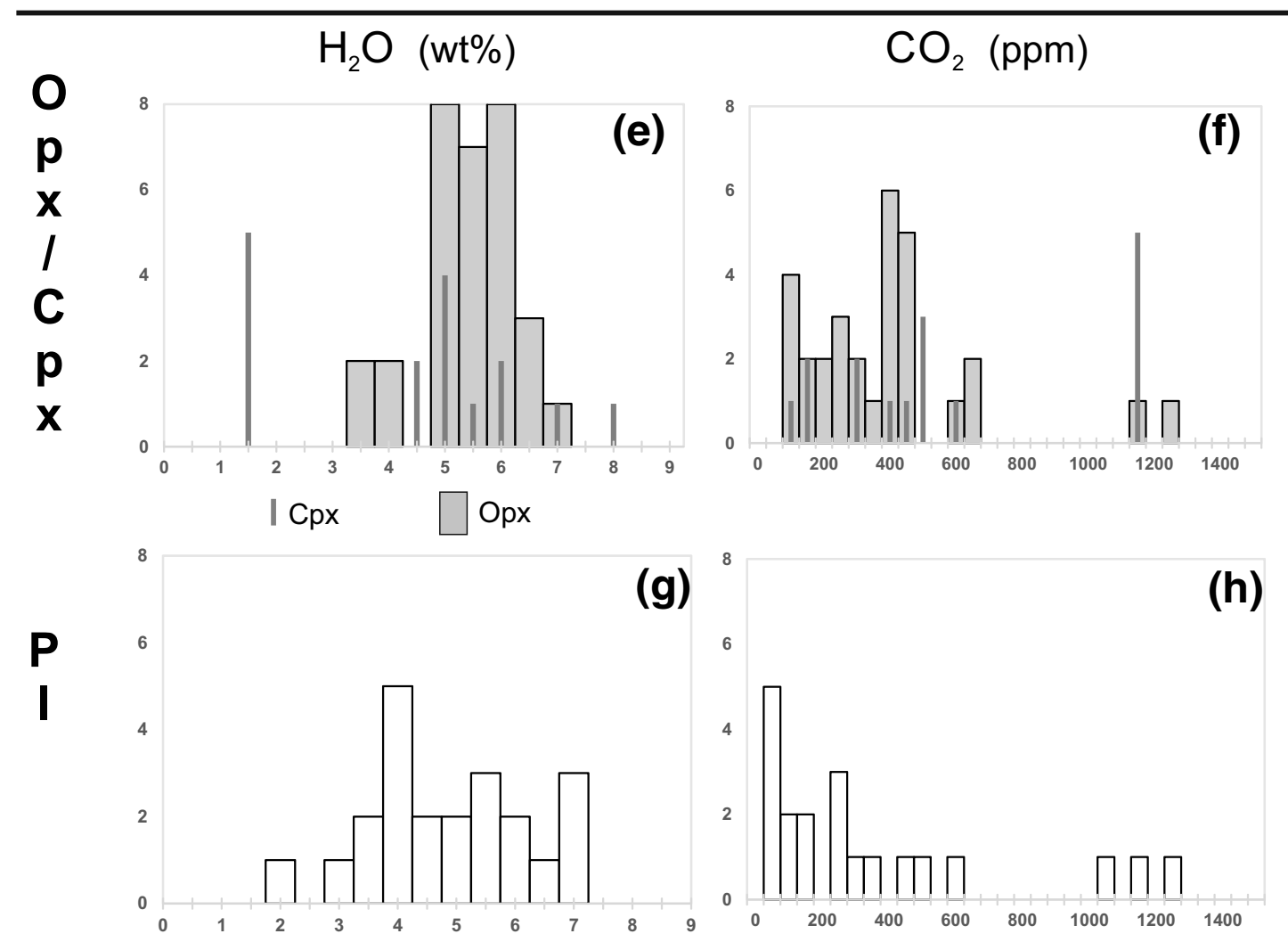


4Fig. 7 Frequency histograms of $\mathrm{CO}_{2}$ and $\mathrm{H}_{2} \mathrm{O}$ contents of the melt inclusions. Morne Diablotins-Morne Trois Pitons-Micotrin is separated from Morne aux Diables for clarity. Host-mineral is specified. Morne aux Diables: opx: grey domain; cpx: dark grey vertical line

Diables MIs describes the same trend, although some Pl-hosted MIs depart from this trend being Cl-rich and $\mathrm{H}_{2} \mathrm{O}$-poor.

Bromine data were acquired only for Opx-hosted MIs from Layou, Roseau and Grand Fond (Fig. 8). They display contrasted $\mathrm{Br}$ contents with a clearly distinct domain for Roseau (13-16 ppm) compared to lower values for Layou (7-13 ppm) and intermediate values for Grand Fond (10-15 ppm). There is no clear relationship between $\mathrm{Br}$ and Th (Fig. 10c). There is a wide range in $\mathrm{Br}$ at almost constant $\mathrm{Cl}$ (Fig. 10f). Like $\mathrm{Cl}$, the $\mathrm{Br}$ concentrations lie at the high end of the global range in silicic magmas reported by Webster et al. (2018).

4. Sulfur Sulfur content of $160 \pm 20 \mathrm{ppm}$ has been measured in a few Opx-hosted MI from Morne Diablotins and Morne Trois Pitons-Micotrin (Fig. 8) Sulfur in Morne aux Diables MIs has been more extensively investigated. MIs exhibit higher values, up to 569 ppm in Opx-hosted MIs (with one value at 1015 ppm; off-scale in Fig. 9), 360 ppm for Cpx-hosted MIs and 300 ppm in Pl-hosted MIs (Fig. 9). Sulfur is inversely correlated with Th (Fig. 10d). The low S contents of the melts are consistent with sulfide saturation in silicic melts at pressures of 1-2 kbar and temperatures of 850-900 ${ }^{\circ} \mathrm{C}$ (Carroll and Rutherford 1987). However, daughter sulfide minerals were not identified in any of the MI studied.

\section{Bulk scoria fallout composition}

The studied mafic samples collected from the southwestern coast of Dominica are basaltic in bulk composition (TAS classification, Fig. 3a), with $\mathrm{SiO}_{2}$ between 49 and 51 wt\% and $\mathrm{Na}_{2} \mathrm{O}+\mathrm{K}_{2} \mathrm{O}$ between 2.5 and $4.5 \mathrm{wt} \%$. Their bulk trace element signature describes the same linear trend in U-Th space as the more differentiated products $(\mathrm{U}=0.3-0.4 \mathrm{ppm}$, Th $=1-1.4$ ppm) (Fig. 5a). The mafic samples are homogeneous composition in $\mathrm{Rb}, \mathrm{Zr}$, and even $\mathrm{Ba}$ (Fig. 5b-d).

\section{Discussion}

We first discuss the major and trace element MI compositions, then the volatile contents. Plat Pays Volcanic Complex MIs, using data from Gurenko et al. (2005) are included in the discussion at the scale of Dominica, in terms of a comparison of pre-eruptive conditions of magma storage and ascent.

\section{MI composition in equilibrium: test through $\mathrm{Kd}$ determination}

Although MIs provide valuable information concerning the pre-eruptive melt volatile contents, they are prone to post-entrapment modification such as post-entrapment crystallization (PEC), involving growth of the host crystal or daughter crystals, or leakage and decrepitation, diffusion of volatile species through the host crystals (or exchange between host and melt) or partitioning of volatile species into shrinkage bubbles. These potential problems need to be evaluated where possible (Wallace 2005; Esposito et al. 2014).

As we have avoided MIs with bubbles, that may contain significant exsolved $\mathrm{CO}_{2}$, we will confine our discussion of post-entrapment modification to tests of equilibrium between MI (Table 1) and their host crystal (SI4 and SI5). For this exercise we use the exchange coefficient $K_{\mathrm{D}}(\mathrm{Fe}-\mathrm{Mg}) O p x$ $l i q=0.23 \pm 0.02$ for Opx and $K_{\mathrm{D}}(\mathrm{An}-\mathrm{Ab}) p l-l i q=2.46 \pm 0.09$ for Pl (Solaro-Müller 2017). These exchange coefficients are taken from Opx-melt and Pl-melt compositions of phase equilibria experiments conducted on Layou and Roseau dacites, between 1.5 and 4 kbars and 800-900 ${ }^{\circ} \mathrm{C}$ (SolaroMüller 2017; Solaro et al. in revision). The experimental $K_{\mathrm{D}}((\mathrm{Fe}-\mathrm{Mg}) O p x$ - liq from these experiments $(0.23 \pm 0.02)$ is slightly lower than that proposed by Putirka (2008) at $0.29 \pm 0.06$. Considering that his value decreases slightly with increased silica content we calculate, following Putirka's (2008) proposed influence of $\mathrm{SiO}_{2}$, a $K_{\mathrm{D}}((\mathrm{Fe}-\mathrm{Mg}) O p x-$ $l i q$ value for Dominica magmas of 0.19-0.20, slightly closer to our experimental value. As the value of 0.23 is based on experiments performed on the actual magma compositions studied here, it is preferred to test equilibrium of MI. Using $K \mathrm{D}(\mathrm{Fe}-\mathrm{Mg}) O p x$-liq $=0.23$ we calculate that Opx-MI show only minor evidence of PEC at $1-2 \%$. The experimentallydetermined $K_{\mathrm{D}}(\mathrm{An}-\mathrm{Ab}) p l$-liq of $2.46 \pm 0.09$ for $\mathrm{Pl}$ in the $\mathrm{T}$, $\mathrm{P}$ and composition range studied experimentally by SolaroMüller (2017), was used to constrain post-entrapment evolution of MIs. Contrary to Opx, Pl-hosted MIs exhibit PEC between 0 and 19\%. Only Pl-hosted MIs showing PEC below $8 \%$ have been selected for plotting and discussion. Note that the amounts of calculated PEC for both Opx- and Pl-hosted inclusions has little bearing on the measured volatile contents, being limited to major elements in both Opx and Pl.

\section{Volatile content and behavior: implications for pre-eruptive magma storage}

Melt inclusions reveal high volatile contents, in particular $\mathrm{H}_{2} \mathrm{O}$, for the pre-eruptive magma storage reservoir in central and northern Dominica. Frequency histograms highlight that some $\mathrm{MI}$ in Opx have $\mathrm{H}_{2} \mathrm{O}$ content up to 7.6 and $7.5 \mathrm{wt} \%$ for Layou and Roseau, respectively, similar to Morne aux 


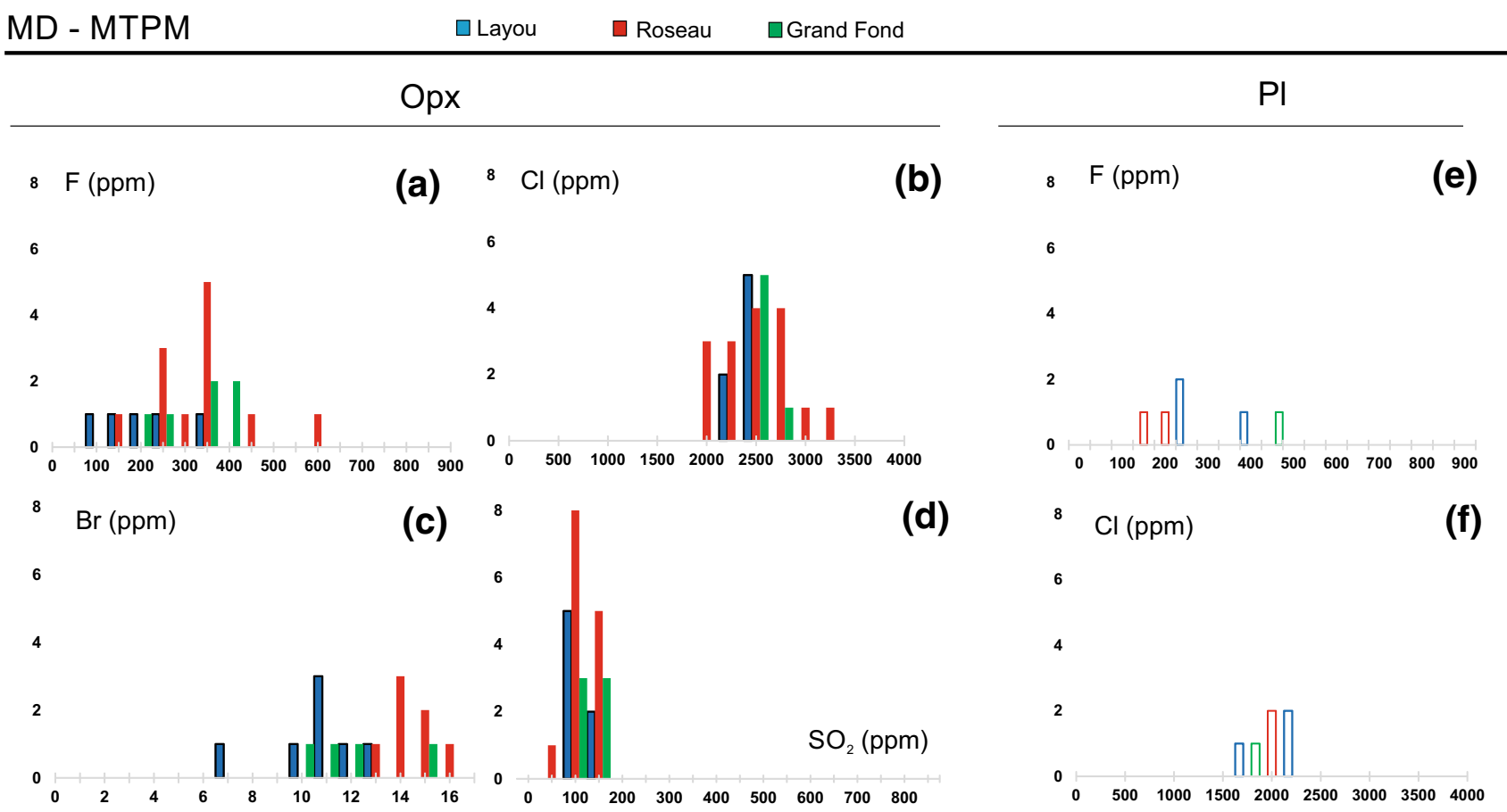

MAD
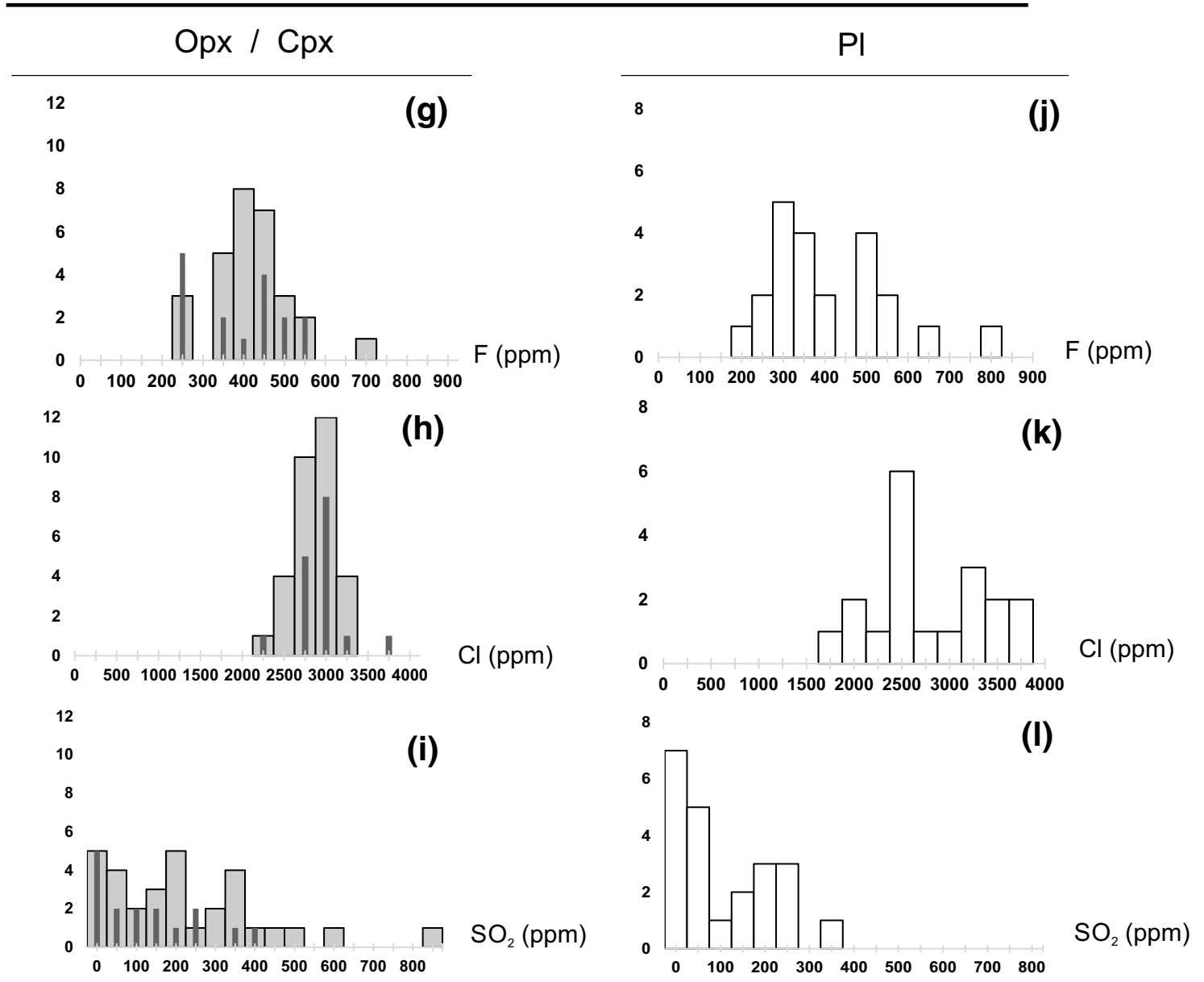
4Fig. 8 Frequency histograms of halogen $(\mathrm{F}, \mathrm{Cl}, \mathrm{Br})$ and $\mathrm{SO}_{2}$ contents of melt inclusions. Morne Diablotins-Morne Trois Pitons-Micotrin is separated from Morne aux Diables for clarity. Host-mineral is specified. Morne aux Diables: opx: grey domain; cpx: dark grey vertical line

Diables with 7.6 wt\%, whereas Grand Fond show lower maximum $\mathrm{H}_{2} \mathrm{O}$ content (6.3 wt\%). Layou consistently exhibits higher $\mathrm{H}_{2} \mathrm{O}$ content MIs than Roseau, with $70 \%$ of the MIs containing more than $7 \mathrm{wt} \%$. As MIs with $\mathrm{H}_{2} \mathrm{O}$ content higher than $7 \mathrm{wt} \%$ are rarely reported, our data place the central Dominica magmas amongst the wettest in the world, comparable, for example, to dacites from Pinatubo, Philippines (Wallace 2005). Edmonds et al. (2016) have proposed similarly $\mathrm{H}_{2} \mathrm{O}$-rich andesite magmas $(\leq 9.4 \mathrm{wt} \%)$ for Soufriere Hills Volcano, Montserrat, on the indirect basis of the $\mathrm{H}$ content of orthopyroxene phenocryst cores. On this basis, they invoke magma storage at depths of 5-16 km beneath Montserrat. For comparison, Laumonier et al. (2017) suggest, on the basis of electrical conductivity and experimental phase relations, that andesitic partial melt in the AltiplanoPuna Magma Body $15 \mathrm{~km}$ beneath the Bolivian Altiplano contains $8-10 \mathrm{wt} \% \mathrm{H}_{2} \mathrm{O}$.

\section{Melt inclusion pressure of entrapment}

MI volatile contents may be converted into minimum pressures of entrapment using joint $\mathrm{H}_{2} \mathrm{O}-\mathrm{CO}_{2}$ solubility models (Fig. 9b), providing that melts are volatile-saturated at the time of entrapment as demonstrated for Morne Diablotins and Morne Trois Pitons-Micotrin MIs by a negative correlation between $\mathrm{CO}_{2}$ and Th (Fig. 9a; Blundy and Cashman 2008).

\section{$\mathrm{H}_{2} \mathrm{O}-\mathrm{CO}_{2}$ content}

Various solubility models using mixed $\mathrm{H}_{2} \mathrm{O}-\mathrm{CO}_{2}$ fluids have been developed, including Tamic et al. (2001), Newman and Lowenstern (2002), Papale et al. (2006) and Ghiorso and Gualda (2015). The two latest models are calibrated on published experimental data on $\mathrm{H}_{2} \mathrm{O}$ and $\mathrm{CO}_{2}$ solubility as well as mixed fluids. "Magmasat" (Ghiorso and Gualda 2015) is used here to calculate saturation pressure and volatile compositions for all volcanic centers. As Magmasat is a compositionally-sensitive solubility model, it is not straightforward to calculate isobars in $\mathrm{CO}_{2}-\mathrm{H}_{2} \mathrm{O}$ space for MIs that span a range of compositions. For this purpose we have used the generic "VolatileCalc" rhyolite solubility model of Newman and Lowenstern (2002) to show representative isobars in Fig. 9b. For individual MIs we performed Magmasat calculations using the measured major element composition, an assumed $\mathrm{fO}_{2}$ of NNO to determine ferric-ferrous ratios and at temperatures calculated from mineral-melt thermometry.
Where this was not possible we used an estimated temperature of $890{ }^{\circ} \mathrm{C}$.

Considering the entire MI dataset, magmas erupted during Dominica's large pumiceous eruptions (Morne Diablotins and Morne Trois Pitons-Micotrin) equilibrated at pressures of 1.5 to $7.5 \mathrm{kbar}$. This corresponds to a depth range of 5-27 km, supposing lithostatic pressure and a crustal density of $2800 \mathrm{~kg} / \mathrm{m}^{3}$ (Fig. 9c). Similarly, for Morne aux Diables, with the exception of a single ruptured inclusion (0.09 kbar), magmas originated from 0.8 to $5.8 \mathrm{kbar}$ (3-21 km depth). The maximum depths lie close to the crustal thickness $(28 \mathrm{~km})$ beneath northern Dominica as determined by the seismic experiment of Kopp et al. (2011). This deep origin for silicic magmas is compatible with the transcrustal magmatic system proposed by Blundy and Cashman (2008) and Cashman et al. (2017) and the mush model inferred for sub-volcanic magma storage (Solaro-Müller 2017; Bachmann and Huber 2016). Cumulate troctolite and gabbronorite xenoliths from Dominica, described by Ziberna et al. (2017), record equilibration conditions of $1.9 \pm 0.9$ to $3.6 \pm 0.8 \mathrm{kbar}(7 \pm 4$ to $13 \pm 3 \mathrm{~km}$ depth $)$, again consistent with magma storage and differentiation over a wide range of crustal depths.

Fluid compositions, expressed as $\mathrm{XH}_{2} \mathrm{O}=$ molar $\mathrm{H}_{2} \mathrm{O}$ / $\left(\mathrm{H}_{2} \mathrm{O}+\mathrm{CO}_{2}\right)$, calculated using Magmasat are in the range 0.7-1.0 for the majority of MIs with trapping pressures of 1-3 kbar (Fig. 9c). However, the highest pressure MIs show a trend to lower $\mathrm{XH}_{2} \mathrm{O}$, consistent with decompression-driven degassing, accompanied by crystallization, that serves to increase $\mathrm{XH}_{2} \mathrm{O}$ as degassing proceeds (Blundy and Cashman 2008). Kilgour et al. (2013) observed a similar $X \mathrm{H}_{2} \mathrm{O}-\mathrm{P}$ variation for melt inclusions from Ruapehu. There are also some lower pressure Dominica MIs with $X_{2} \mathrm{H}_{2} \mathrm{O}<0.7$ (Fig. 9c). This behavior is reminiscent of fluxing of shallower-stored magmas with deep-derived $\mathrm{CO}_{2}$-rich fluids, as proposed for a number of arc volcanoes (e.g. Blundy et al. 2010; Caricchi et al. 2018). Fluxing of shallow magmas with deep-derived fluids is consistent with a vertically extensive system of fluid-rich magmas in which melt and fluid movement can become decoupled (e.g. Christopher et al. 2015).

Systematic variations between different volcanic centers can be used to evaluate spatial and temporal variations in magma storage conditions. For Layou, magma storage pressures are the greatest of the three large pumiceous eruptions from central Dominica, with a range of values between 2.5 and $3.5 \mathrm{kbar}(9-13 \mathrm{~km})$, with most Opx values between 3.0 and 3.5 kbar. Roseau Opx MIs span a large, rather continuous, domain of pressure between 2.0 and $3.0 \mathrm{kbar}$ (7-11 km), with a single value at $1.5 \mathrm{kbar}$. Grand Fond Opx MIs describe a narrower domain of pressure, the shallowest of the three eruptions, between 1.6 and $2.7 \mathrm{kbar}(6-10 \mathrm{~km})$. However, a single Grand Fond MI records the highest pressure (7.5 kbar), suggestive of some entrainment of host 
Fig. $9 \mathrm{H}_{2} \mathrm{O}-\mathrm{CO}_{2}$ behaviour. a $\mathrm{CO}_{2}$ vs. $\mathrm{H}_{2} \mathrm{O}$ variations with generic $850{ }^{\circ} \mathrm{C}$ rhyolite isobars from VolatileCalc for reference. $\mathbf{b ~ C O}$ vs. Th relationship. c Calculated $\mathrm{XH}_{2} \mathrm{O}$ of coexisting fluid vs. trapping pressure (kbar) as calculated for individual melt inclusions. Symbols as in Fig. 3

crystals from the Dominica lower crust. For the three eruptions, MIs in Pl from Roseau and Layou correspond to lower calculated pressures compared to MIs in Opx. We may thus infer that the likely depth range for the magma feeding to the Roseau and Grand Fond eruptions from the Morne Trois Pitons-Micotrin center is $6-11 \mathrm{~km}$, and slightly deeper for the Morne Diablotins -derived Layou eruption (9-13 km). This general pressure range agrees with phase equilibria experiments conducted on the same sample set that suggests equilibration at 3.0-3.5 kbar (Solaro-Müller 2017, in revision). For Morne aux Diables, the bulk of the MI correspond to the same pressure and depth domain $(0.8-4 \mathrm{kbar}$, 3-15 km) as for Morne Diablotins and Morne Trois PitonsMicotrin, but with a few Pl-hosted MI recording pressures up to $5.7 \mathrm{kbar}$ (Fig. 8c), again suggestive of some deeper silicic melt generation and extraction.

\section{Halogen signature}

The entrapment pressure recorded by MI may be also extracted from $\mathrm{H}_{2} \mathrm{O}-\mathrm{Cl}$ solubility relations (Webster et al. 1999; Fig. 11). Experimental determinations of $\mathrm{Cl}$ solubility show that $\mathrm{H}_{2} \mathrm{O}$ and $\mathrm{Cl}$ content may be used together as a geobarometer for magmas of rhyolitic composition (Webster et al. 1999). Chlorine contents of Dominica MIs show a wide range of values (Figs. 8, 11), regardless of the eruption, but with the highest content for Morne aux Diables and the lowest content Morne Diablotins and Morne Trois Pitons-Micotrin. For Morne Diablotins and Morne Trois Pitons-Micotrin the values of MI in Pl correspond to lower pressure, close to $2 \mathrm{kbar}$, whereas Opx-hosted MI indicate higher pressure. For Morne aux Diables most of the MIs in Opx indicate a pressure roughly equivalent to that obtained for the MIs in Opx for Morne Diablotins and Morne Trois Pitons-Micotrin. Based on the experimental data of Webster (1997), these MIs are consistent with pressures above 2 kbars; however, $\mathrm{Cl}$ contents of melts afford significantly lower precision pressure estimates than those obtained by $\mathrm{H}_{2} \mathrm{O}-\mathrm{CO}_{2}$ solubility models.

For Morne Diablotins and Morne Trois Pitons-Micotrin the matrix glass composition has a mean $\mathrm{Cl}$ content of $2380 \pm 200 \mathrm{ppm}$ (Boudon et al. 2017) similar to MI values (Fig. 11). Chlorine behavior is generally related to $\mathrm{H}_{2} \mathrm{O}$ through the partition coefficient of $\mathrm{Cl}$ into the $\mathrm{H}_{2} \mathrm{O}$-rich vapor phase (Kilinc and Burnham 1972; Webster and Holloway 1988). But here, given the similar values between MI and the matrix glass, degassing processes at shallow depth
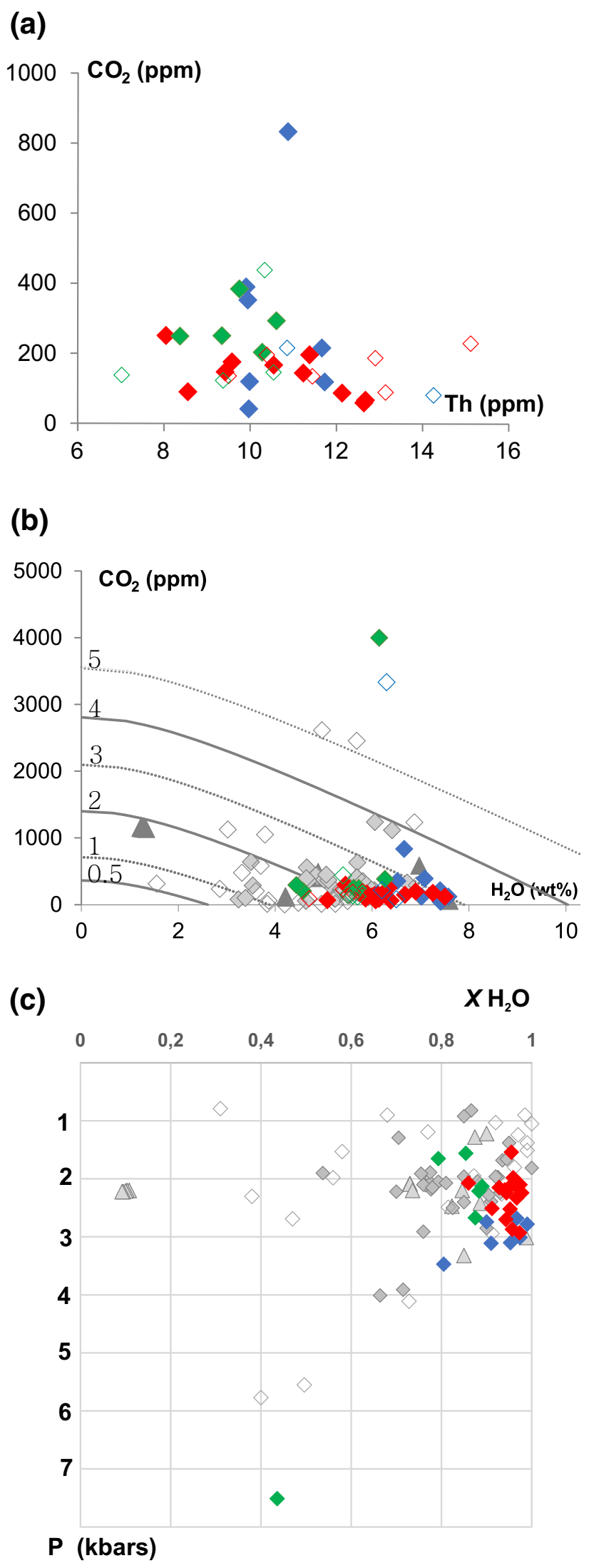

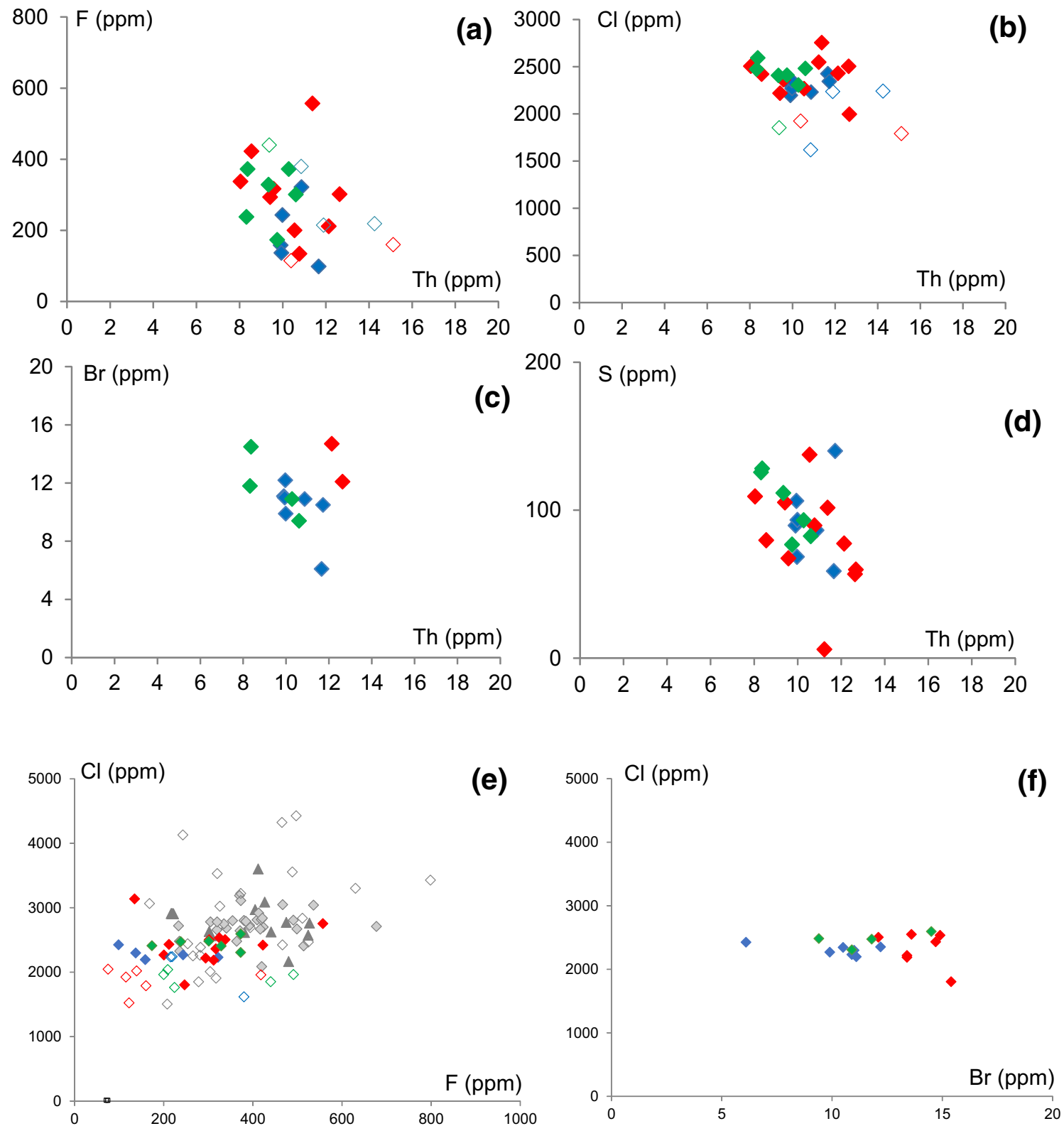

Cpx-host MI

Opx-host MI

Plag-host MI

$\triangle$ MAD

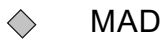

$\diamond \quad \mathrm{MAD}$

MD - Layou

$\diamond \quad$ MD - Layou

MTPM - Roseau

$\diamond$ MTPM - Roseau

MTPM - Grand Fond

$\diamond$ MTPM - Grand Fond

Fig. 10 Halogen and sulfur behaviour. a $\mathrm{F}$ vs. Th; $\mathbf{b} \mathrm{Cl}$ vs. Th; $\mathbf{c} \mathrm{Br}$ vs. Th; d S vs. Th; e $\mathrm{Cl}$ vs. F; f $\mathrm{Cl}$ vs. $\mathrm{Br}$

during magma ascent do not appear to be the dominant processes controlling the $\mathrm{Cl}$ content of magmas (Fig. 11). The different $\mathrm{Cl}$ signature between the different volcanic centers is likely to be inherited from magma source at depth without significant modification by degassing processes
(Balcone-Boissard et al. 2010): the parental magmas to Morne aux Diables, Morne Diablotins and Morne Trois Pitons-Micotrin eruptions have different initial $\mathrm{Cl}$ content. All MIs, regardless of provenance, describe the same $\mathrm{Cl} / \mathrm{F}$ correlation $(8.3 \pm 2.7)$, indicating that the magma source 
Fig. $11 \mathrm{H}_{2} \mathrm{O}$ vs. $\mathrm{Cl}$ variation. Purple dashed lines denotes Plat Pays Volcanic Complex MI composition for Opx and $\mathrm{Pl}$ from Gurenko et al. (2005). The $2 \mathrm{kbar}$ isobar is from Webster (1997). Symbols as in Fig. 3. Dashed brown lines give the weight percentage of $\mathrm{NaCl}$ in aqueous fluids required to produce the observed $\mathrm{Cl} / \mathrm{H}_{2} \mathrm{O}$ ratios

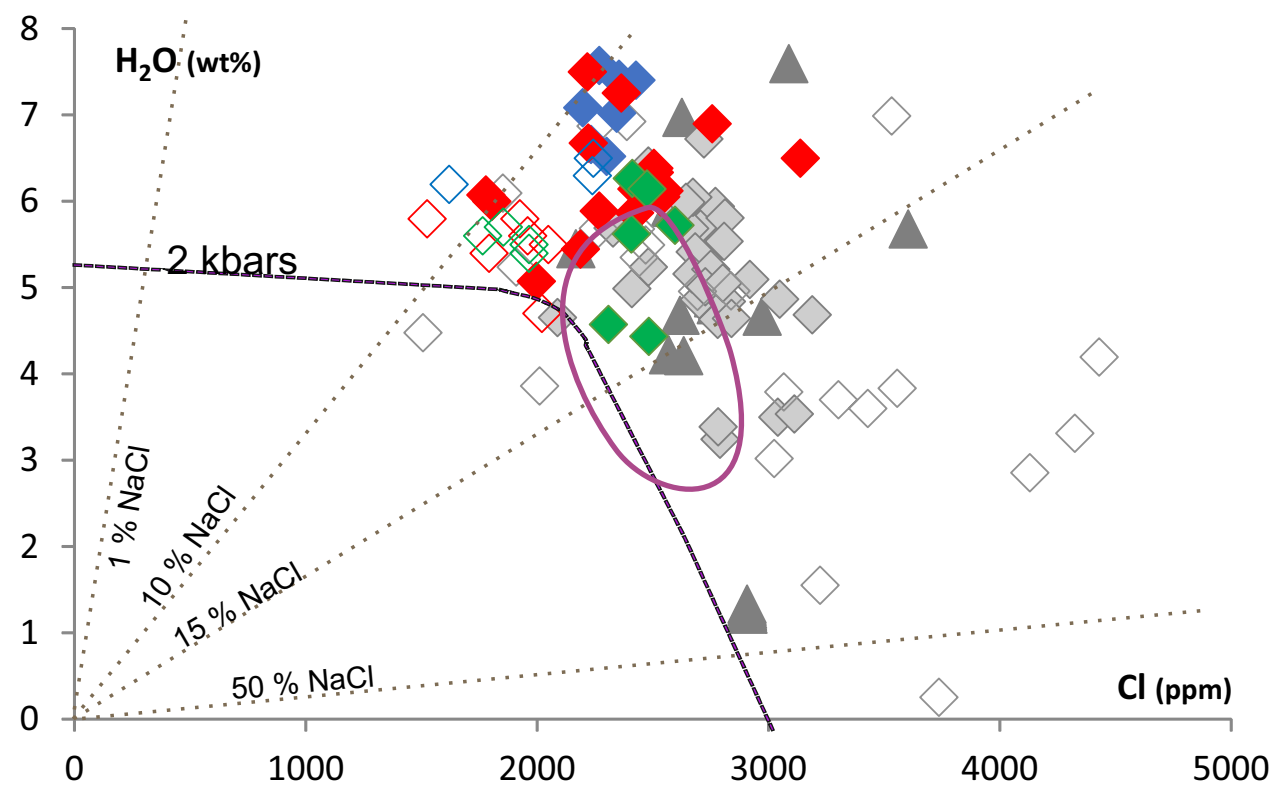

\begin{tabular}{llll} 
Cpx-host MI & \multicolumn{2}{l}{ Opx-host MI } & $\underline{\text { Plag-host MI }}$ \\
$\triangle$ MAD & $\diamond$ MAD & $\diamond$ MAD \\
& $\diamond$ MD - Layou & $\diamond$ & MD - Layou \\
& $\diamond$ MTPM - Roseau & $\diamond$ & MTPM - Roseau \\
& $\diamond \quad$ MTPM - Grand Fond & $\diamond$ & MTPM - Grand Fond
\end{tabular}

PPVC MI domain

$\mathrm{Cl}$ solubility curve at 2 kbars

$\mathrm{NaCl}$ aqueous fluids at depth is similar (Fig. 10e). The $\mathrm{Cl}-\mathrm{Br}$ diagram shows large variations in $\mathrm{Br}$ content with respect to $\mathrm{Cl}$ that remains roughly constant (Fig. 10f). The large range of $\mathrm{Br} / \mathrm{Cl}$ ratio may be linked to variable assimilation rate of seawaterderived brines.

\section{Comparison with other volcanic system from Dominica and the Lesser Antilles arc}

Here, we review the information on magma plumbing system architecture and dynamics within Dominica and the wider Lesser Antilles arc, looking at the volatile content of melts as well as insights from experimental petrology.

Dominica:

\section{Plat Pays Volcanic Complex (PPVC)}

Magma storage pressures can only be discussed using $\mathrm{Cl}-\mathrm{H}_{2} \mathrm{O}$ data for the dacites of Plat Pays Volcanic Complex in the last 40 kyrs (Gurenko et al. 2005; Fig. 8) as no $\mathrm{CO}_{2}$ data were obtained by these authors. For Plat Pays Volcanic Complex, the total range of $\mathrm{H}_{2} \mathrm{O}$ contents in pumice (airfall deposits) is 2-6 wt \% and, generally, MIs in Opx have higher water concentrations than those in Pl. The highest pre-eruptive $\mathrm{H}_{2} \mathrm{O}$ content is thus consistent with other MIs investigations that provide $5.2-6.5 \mathrm{wt} \%$ for pre-eruptive melt (Halama et al. 2006). The MI Cl contents in Plat Pays Volcanic Complex describe a wide range of values, between 1500 and 3500 ppm (Gurenko et al. 2005; Halama et al. 2006). Based on $\mathrm{H}_{2} \mathrm{O}-\mathrm{Cl}$ solublity, the dacitic magma feeding the recent volcanic activity of Plat Pays Volcanic Complex was stored at $\sim 2$ kbars (Fig. 11). This pressure is similar with those based on melt $\mathrm{H}_{2} \mathrm{O}$ solubility (Ghiorso and Gualda 2015) suggestive of relatively low $\mathrm{CO}_{2}$ contents.

\section{Lesser Antilles arc}

\section{Montagne Pelée (Martinique)}

The pre-eruptive conditions, either for Plinian or lava domeforming eruption, at Montagne Pelée (Martinique) were determined experimentally by Martel et al. (1998). For pumice clasts from recent Plinian eruptions, a pressure of $2 \pm 0.5$ kbars (depth 6-9 km) and a $\mathrm{H}_{2} \mathrm{O}$ melt content of 5.3-6.3 wt\% (slightly below the saturation value of $\sim 6.9 \mathrm{wt} . \% \mathrm{H}_{2} \mathrm{O}$ ) were determined. MIs have a $\mathrm{Cl}$ concentration of $2100 \pm 100 \mathrm{ppm}$ (Villemant and Boudon 1998; Balcone-Boissard et al. 2010), which corresponds, when combined with $\mathrm{H}_{2} \mathrm{O}$, to the lower 
end of the range for central and northern Dominica samples. In addition, the last 40,000 years of activity of the volcano highlights the presence of mafic magmas beneath Montagne Pelée, even though the most recently erupted products have andesite bulk compositions. Therefore, the magma storage zone is best viewed as a compositionally zoned igneous system, with a mafic part and an andesitic part (Pichavant et al. 2002). The crystallization of mafic magma occurs through a substantial pressure range of 4-10 kbars consistent with the upper end of the pressures recorded by Dominica MIs. Evolution toward more silicic composition is related to amphibole crystallization at low $\mathrm{T}\left(<1000^{\circ} \mathrm{C}\right)$. Plutonic xenoliths from Martinique have mineral assemblages consistent with pressures $\leq 4 \mathrm{kbar}$ (Cooper et al. 2016).

\section{Soufrière (Guadeloupe)}

Magma storage conditions have also been determined by experimental petrology, specifically for the last subplinian magmatic eruption that occurred in 1530 AD (Poussineau 2005). The most likely pressure domain of the reservoir is between 1.35 and 1.7 kbars, with a maximum at 2 kbars. Recently, new data on MI in the eruptive products of the $1530 \mathrm{AD}$ eruption provide a large range of $\mathrm{H}_{2} \mathrm{O}$ content but a maximum $\mathrm{H}_{2} \mathrm{O}$ of $5.5 \mathrm{wt} \%$ (Pichavant et al. 2018). A key factor in explaining the overall behaviour of La Soufrière volcano, seems to be an exceptionally high flux of mafic magma from depth, consistent with continuous chemical zonation and the predominance of the mafic component in eruption products. This observation suggests that magma accumulation at shallow depth primarily depends on processes taking place in the middle to lower part of the arc crust beneath Guadeloupe (Pichavant et al. 2018).

\section{Soufriere Hills Volcano (Montserrat)}

Based on $\mathrm{H}$ content of orthopyroxene phenocryst cores Edmonds et al. (2016) have proposed $\mathrm{H}_{2} \mathrm{O}$-rich andesite magmas $(\leq 9.4 \mathrm{wt} \%)$, interpreted as due to a magma storage at depths of 5-16 km beneath Montserrat. The magma plumbing system beneath this volcano has also been described through the prism of the mush based on the excess of $\mathrm{SO}_{2}$ flux interpreted as resulting from a decoupled sulfur degassing through transcrustal magmatic system. Thus, it is envisaged that Soufriere Hills Volcano is underlain by a vertically extensive large igneous mush system formed over tens of thousands of years and perhaps extending from the shallow crust $(>4 \mathrm{~km}$ ) to the Moho (Christopher et al. 2015). Geophysical images of the crust beneath Montserrat identify a region of partial depth that extends from $5 \mathrm{~km}$ to at least $9 \mathrm{~km}$ (Paulatto et al. 2012).

\section{St. Kitts}

St. Kitts lies in the northern Lesser Antilles. A series of dacitic to rhyolitic MIs with $\mathrm{H}_{2} \mathrm{O}$ content between 2 and $6 \mathrm{wt} \%$, trapped in Opx and Pl from plutonic xenoliths yields calculated saturation pressures from 0.5 to $3.8 \mathrm{kbars}$ (Melekhova et al. 2017). These conditions are corroborated by experiments that show the observed amphibole-bearing assemblages of cumulate xenoliths from St. Kitts require crystallization pressures of 1.5 to $6 \mathrm{kbar}$ from parental hydrous basaltic andesite magmas (Melekhova et al. 2017). These findings were interpreted as corresponding to silicic magmas that ascended and equilibrated at shallow depths following generation from basaltic andesite parents at pressures up to 6 kbars. Thus St. Kitts magmas also testify to mid-crustal differentiation of low-MgO basalt and basaltic andesite magmas within a trans-crustal, magmatic mush system.

\section{Magmatic processes within the reservoir}

The emerging concept of a crustal magmatic reservoir is moving away from a single volume of melt (magma chamber) towards the idea of a crystal mush, comprising partial melt within a crystalline framework that can extend more or less continuously throughout a crustal column. Within this dynamic zone, magma accumulates, differentiates, and can become destabilized, leading to eruption (Christopher et al. 2015; Cashman et al. 2017). Matrix glass records the final, degassed melt that is quenched throughout the fragmentation process during eruption. Conversely, MIs represent the pre-eruptive melt at different stages of the differentiation process. Thus, comparing matrix glass and MI composition can be helpful to constrain pre-eruptive dynamics. The analyzed MIs of this study have suffered little post-entrapment crystallization, especially for Opx, and so may be used as a proxy for magma generation and ascent processes.

Comparison of matrix glass and MI from all three large pumiceous eruptions from Morne Diablotins and Morne Trois Pitons-Micotrin shows, somewhat surprisingly, that MI trapped in Opx (and Pl) are more differentiated than the matrix glass (Fig. 5a-c). This difference in composition is more clearly preserved through trace elements than major elements. Because the melts have major element compositions close to the granitic minimum (eutectic) the effects of different melt fraction are much more pronounced for incompatible trace elements than for major elements. Trace element variations, in particular in $\mathrm{Ba}-\mathrm{Th}$ or $\mathrm{Rb}-\mathrm{Zr}$ (Fig. 5 c, d), do not support the evolution of the matrix glass through simple decompression crystallization of the trapped melt as recorded by MIs. The behavior of $\mathrm{Zr}$ is consistent with zircon saturation in the MI, but not in the matrix glasses. Consequently, the MI appear to be trapped aliquots of evolved 
melt formed at lower temperatures. In contrast, the higher temperatures recorded by MI-Opx and Fe-Ti oxide thermometry suggest that prior to eruption phenocrysts experienced temperatures some $100{ }^{\circ} \mathrm{C}$ higher. This temperature increase could be related to the release of latent heat of crystallization, which is of the order $2.5^{\circ} \mathrm{C}$ for each percent crystallised (Blundy et al. 2006). Conversely, eruption could have been preceded by a recharge event followed by efficient mixing that produces a less differentiated matrix melt or by mixing between different parts of the same mush displaying different degrees of melt differentiation. Melt-bearing mush accumulations are highly susceptible to segregation of melt-rich layers by compaction and shear (e.g. Solano et al. 2012). Thus mixing in the mush need not necessarily involve a mafic magma, since a recharge with a hotter, slightly less evolved silicic magma may also occur and will leave little vestige of the mixed-in composition. Migrating evolved melts may entrain crystals from portions of the mush that are both cooler and more crystallized. In that case, melt inclusions in entrained crystals may record lower temperatures and melt fractions than the carrier magma. We speculate that this process may have operated on Dominica.

Supposing the extreme case of a recharge event by a basic magma (such as that represented by the Dominica scoria clasts), we can calculate mixing proportions between the scoria clasts and the MI composition (Supplementary material SI1). In this way, we estimate a mixing proportion of 25\% for Layou, 5\% for Roseau and 40\% for Grand Fond. Based on this analysis, we may infer that the mixing event is heterogeneous at depth and varies from eruption to eruption. For Layou, the Th contents encompass a large range, from 4 to 7.5 ppm (Fig. 5a). The Grand Fond eruption displays the lowest mixing proportion. Mineralogical evidence for mixing includes An-rich layers in plagioclase and En-rich rims on orthopyroxene. However, hand specimens do not show obvious evidence for mixing such as mafic inclusions or banded pumice that have been reported elsewhere (Boudon et al. 2017). Some mafic enclaves within Micotrin, Trois Pitons, Plat Pays and Grand Soufrière Hills (Howe et al. 2015) lava dome products have similar Th content to the basic scoria, suggesting mixing heterogeneity. Thus, the mixing event may have been efficient enough for explosive eruptions to erase any evidence of the two components on the hand-sample scale. On the other hand, considering the mush model, we may also infer that mixing event occurs between various rhyolitic or dacitic melts that differ slightly in composition and temperature or that the main impact of the mafic magma is heat transfer, since the small changes in overall magma chemistry and the small percentage of relatively intact enclaves do not support extensive mingling.

Our findings contrast with what is observed on Guadeloupe within the $1530 \mathrm{AD}$ eruption deposits that clearly preserve a mixing event prior to eruption through banded pumice and a wide range of composition of the eruptive products attesting to a chemically and physically heterogeneous reservoir at depth (Pichavant et al. 2018). At Montagne Pelée, there is evidence for magma mixing on a macroscopic scale via the presence of mafic enclaves (51-59 $\mathrm{wt} \% \mathrm{SiO}_{2}$ ) and banded rocks in the 1902-1929 lava dome products (Fichaut et al. 1989; Gourgaud et al. 1989). On a microscopic scale, magma mixing is also evidenced by the presence of ubiquitous high-Ca plagioclase microlites, interpreted as crystallizing from a mafic melt intruding the andesitic reservoir (Martel et al. 2006).

\section{Conclusion}

This study highlights the geochemical fingerprint of magmas involved in the three large pumiceous eruptions in the central part of Dominica (Layou, Roseau and Grand Fond) and the dome-forming eruptions of Morne aux Diables in the north. Phenocryst-hosted, silicic melt inclusions, analysed for major, trace and volatile elements, reveal that: (1) these magmas are among the most water-rich yet recorded $\left(\leq 8 \mathrm{wt} \% \mathrm{H}_{2} \mathrm{O}\right)$; (2) magmas are stored pre-eruptively over a wide pressure within the crust (up to $\sim 750 \mathrm{MPa}$ ); (3) deeper magmas are associated with more $\mathrm{CO}_{2}$-rich fluids with evidence for the interaction of such fluids with shallow-stored magmas; and (4) magmatic evolution involved fractional crystallization and magma mixing or melt percolation processes within a vertically extensive magma mush that may extend to the Moho beneath Dominica. This magmatic architecture is consistent with that proposed by Smith et al. (2013). Mixing processes occurred between melts with relatively low contrast in viscosity and/or with sufficient time prior to eruption to homogenize melts, rendering mixing cryptic on Dominica, in contrast to Martinique or Guadeloupe where macroscopic evidence of mixing is preserved. The high water contents of the magmas together with the high proportion of exsolved fluids have implications for the rheology of the mush and timescales for mush reorganization. High water contents can also account for the unusually explosive nature of silicic magmatism on Dominica compared to other Lesser Antilles islands. Vertically-extensive magmatic mushes are consistent with melt inclusion and plutonic xenolith data for other silicic and intermediate eruptions in the northern Lesser Antilles and may be an important aspect of arc magmatism more widely.

Acknowledgements We thank R. Arculus, R. Watts and S. Skora for help with sampling at Morne aux Diables, S. Hidalgo for help with sample preparation, M. Fialin, N. Rividi, S. Kearns and B. Buse for EPMA analyses and O. Boudouma for SEM investigations. This work was supported by the TelluS-ALEAS (2013) funding from INSUCNRS, ERC Advanced Grant CRITMAG and EC FP7 Grant VUELCO. 


\section{References}

Bachmann O, Huber C (2016) Silicic magma reservoirs in the Earth's crust. Am Mineral 101(11):2377-2404. https://doi.org/10.2138/ am-2016-5675

Balcone-Boissard H, Villemant B, Boudon G (2010) Behavior of halogens during the degassing of felsic magmas. Geochem Geophys Geosyst 11:Q09005. https://doi.org/10.1029/2010G C003028

Blundy J, Cashman K (2008) Petrologic reconstruction of magmatic system variables and processes. Rev Mineral Geochem 69:179-239

Blundy J, Cashman K, Humphreys M (2006) Magma heating by decompression-driven crystallization beneath andesite volcanoes. Nature 443(7-107):76-80. https://doi.org/10.1038/nature05100

Blundy J, Cashman KV, Berlo K (2008) Evolving magma storage conditions beneath Mount St. Helens inferred from chemical variations in melt inclusions from the 1980-1986 and current (20042006) eruptions. In: Sherrod DR, Scott WE, Stauffer PH (eds) A volcano rekindled: the renewed eruption of Mount St. Helens, 2004-2006, vol 1750. US Geological Survey Professional Paper, Denver, pp 755-790

Blundy J, Cashman KV, Rust A, Witham F (2010) A case for $\mathrm{CO}_{2}$-rich arc magmas. Earth Planet Sci Lett 290(3-4):289-301. https://doi. org/10.1016/j.epsl.2009.12.013

Boudon G, Le Friant A, Komorowski J-C, Deplus D, Semet MP (2007) Volcano flank instability in the Lesser Antilles Arc: diversity of scale, processes, and temporal recurrence. J Geophys Res 112:B08205. https://doi.org/10.1029/2006JB004674

Boudon G, Balcone-Boissard H, Solaro C, Martel C (2017) A revised chronostratigraphy of recurrent large pumiceous eruptions in Dominica (Lesser Antilles Arc): implications on the behavior of the magma plumbing sytem. J Volcanol Geotherm Res 343:135154. https://doi.org/10.1016/j.jvolgeores.2017.06.022

Bouysse P, Westercamp D (1990) Subduction of Atlantic aseismic ridges and Late Cenozoic evolution of the Lesser Antilles island arc. Tectonophysics 175:349-380. https://doi.org/10.1016/00401951(90)90180-G

Caricchi L, Sheldrake TE, Blundy J (2018) Modulation of magmatic processes by $\mathrm{CO}_{2}$ flushing. Earth Planet Sci Lett 491:160-171

Carroll MR, Rutherford MJ (1987) Sulfur speciation in hydrous experimental glasses of varying oxidation state: results from measured wavelength shifts of sulfur X-rays. Am Mineral 73:845-849

Cashman KV, Sparks RSJ, Blundy JD (2017) Vertically extensive and unstable magmatic systems: a unified view of igneous processes. Science 355:1280. https://doi.org/10.1126/0.1126/science.aag30 55

Christopher TE, Blundy J, Cashman K, Cole P, Edmonds M, Smith P, Sparks RSJ, Stinton A (2015) Crustal-scale degassing due to magma system destabilisation and magma-gas decoupling at Soufrière Hills Volcano, Montserrat. Geochem Geophys Geosyst 16:2797-2811

Cooper GF, Davidson JP, Blundy JD (2016) Plutonic xenoliths from Martinique, Lesser Antilles: evidence for open system processes and reactive melt flow in island arc crust. Contrib Miner Petrol 171:87

Edmonds M, Kohn SC, Hauri EH, Humphreys MCS, Cassidy M (2016) Extensive, water-rich magma reservoir beneath southern Montserrat. Lithos 252-253:216-233. https://doi.org/10.1016/j.litho s.2016.02.026

Esposito R, Hunter J, Schiffbauer JD, Shimizu N, Bodnar RJ (2014) An assessment of the reliability of melt inclusions as recorders of the pre-eruptive volatile content of magmas. Am Mineral 99:976-998
Fichaut M, Maury RC, Traineau H, Westercamp D, Joron J-L, Gourgaud A, Coulon C (1989) Magmatology of Mt Pelée (Martinique FWI). III: fractional crystallisation versus magma mixing. J Volcanol Geotherm Res 38:189-213

Ghiorso MS, Evans BW (2008) Thermodynamics of rhombohedral oxide solid solutions and a revision of the Fe-Ti twooxide geothermometer and oxygen-barometer. Am J Sci 308(9):957-1039

Ghiorso MS, Gualda GAR (2015) $\mathrm{An}_{2} \mathrm{O}-\mathrm{CO}_{2}$ mixed fluid saturation model compatible with rhyolite-MELTS. Contrib Mineral Petrol. https://doi.org/10.1007/s00410-015-1141-8

Gourgaud A, Fichaut M, Joron JL (1989) Magmatology of Mt. Pelée (Martinique FWI). I: Magma mixing and triggering of 1902 and 1929 nuées ardentes. J Volcanol Geotherm Res 38:143-169

Gurenko AA, Trumbull RB, Thomas R, Lindsay JM (2005) A melt inclusion record of volatiles, trace elements and $\mathrm{Li}-\mathrm{B}$ isotope variations in a single magma system from the Plat Pays Volcanic Complex, Dominica, Lesser Antilles. J Pet 46:2495-2526

Halama R, Boudon G, Villemant B, Joron J-L, Le Friant A, Komorowski J-C (2006) Pre-eruptive crystallization conditions of mafic and silicic magmas at the Plat Pays volcanic Complex, Dominica (Lesser Antilles). J Volcanol Geotherm Res 151:200-220

Howe TM, Lindsay JM, Shane P, Schmitt AK, Stockli DF (2014) Reevaluation of the Roseau Tuff eruptive sequence and other Ignimbrites in Dominica, Lesser Antilles. J Quat Sci 29(6):531-546. https://doi.org/10.1002/jqs.2723

Howe TM, Lindsay JM, Shane P (2015) Evolution of young andesiticdacitic magmatic systems beneath Dominica, Lesser Antilles. J Volcanol Geotherm Res 297:69-88. https://doi.org/10.1016/j. jvolgeores.2015.02.009

Kilgour G, Blundy J, Cashman K, Mader HM (2013) Small volume andesite magmas and melt-mush interactions at Ruapehu, New Zealand: evidence from melt inclusions. Contrib Mineral Petrol $1: 1-22$

Kilgour G, Saunders K, Blundy J, Cashman K, Scott B, Miller C, Mader H (2014) Timescales of magmatic processes at Ruapehu volcano from diffusion chronometry and their comparison to monitoring data. J Volcanol Geotherm Res 1:1-14

Kilinc IA, Burnham CW (1972) Partitioning of chloride between a silicate melt and coexisting aqueous phase from 2 to $8 \mathrm{kbars}$. Econ Geol 67:231-235

Kopp H, Weinzierl W, Becel A, Charvis P, Evain M, Flueh ER, Gailler A, Galve A, Hirn A, Kandilarov A, Klaeschen D, Laigle M, Papenberg C, Planert L, Roux E (2011) Deep structure of the central Lesser Antilles Island Arc: relevance for the formation of continental crust. Earth Planet Sci Lett 304(1-2):121-134. https ://doi.org/10.1016/j.eps1.2011.01.024

Labanieh S, Chauvel C, Germa A, Quidelleur X (2012) Martinique: a clear case for sediment melting and slab dehydration as a function of distance to the trench. J Pet 53(12):2441-2464. https://doi. org/10.1093/petrology/egs055

Laumonier M, Gaillard F, Muir D, Blundy J, Unsworth M (2017) Giant magmatic water reservoirs at mid-crustal depth inferred from electrical conductivity and the growth of the continental crust. Earth Planet Sci Lett 457:173-180. https://doi.org/10.1016/j. epsl.2016.10.023

Le Friant A, Boudon G, Komorowski J-C, Deplus C (2002) L'île de la Dominique: zone d'émission des avalanches de débris les plus volumineuses de l'arc des Petites Antilles. C R Geosci 334:235-243

LeBas MJ, LeMaitre RW, Streckeisen A, Zanettin B (1986) A chemical classification of volcanic rocks based on the total alkali-silica diagram. J Petrol 27:745-750 
Lindsay JM, Stasiuk MV, Shepherd JB (2003) Geological history and potential hazards of the late-Pleistocene to Recent Plat Pays volcanic complex, Dominica, Lesser Antilles. Bull Volcanol 65:201-220

Lindsay J, Smith AL, Roobol MJ, Stasiuk MV (2005) Dominica. In: Lindsay JM, Robertson REA, Shepherd JB, Ali S (eds) Volcanic Hazard Atlas of the Lesser Antilles. Seismic Research Unit. The University of West Indies, Trinidad, pp 1-48

Macdonald R, Hawkesworth CJ, Heath E (2000) The Lesser Antilles volcanic chain: a study in arc magmatism. Earth Sci Rev 49:1-76. https://doi.org/10.1016/S0012-8252(99)00069-0

Martel C, Pichavant M, Bourdier J-L, Traineau H, Holtz F, Scaillet B (1998) Magma storage conditions and control of eruption regime in silicic volcanoes: experimental evidence from Mt. Pelée. Earth Planet Sci Lett 156:89-99

Martel C, Ali AR, Poussineau S, Gourgaud A, Pichavant M (2006) Basalt-inherited microlites in silicic magmas: evidence from Mount Pelée (Martinique, French West Indies). Geology 34(11):905-908. https://doi.org/10.1130/G22672A.1

Melekhova E, Blundy J, Martin R, Arculus R, Picahvant M (2017) Petrological and experimental evidence for differentiation of waterrich magmas beneath St. Kitts, Lesser Antilles. Contrib Mineral Petrol 172:98. https://doi.org/10.1007/s00410-017-1416-3

Moore $\mathrm{G}$ (2008) Interpreting $\mathrm{H}_{2} \mathrm{O}$ and $\mathrm{CO}_{2}$ contents in melt inclusions: constraints from solubility experiments and modeling. Rev Mineral Geochem 69(5):333-361

Muir DD, Blundy J, Rust AC, Hickey J (2014) Experimental constraints in dacite pre-eruptive magma storage conditions beneath Uturuncu volcano. J Pet. https://doi.org/10.1093/petrology/ egu005

Newman S, Lowenstern JB (2002) VolatileCalc: a silicate melt- $\mathrm{H}_{2} \mathrm{O}-$ $\mathrm{CO}_{2}$ solution model written in Visual Basic for excel. Comput Geosci 28(5):597-604

Papale P, Moretti R, Barbato D (2006) The compositional dependence of the saturation surface of $\mathrm{H}_{2} \mathrm{O}+\mathrm{CO}_{2}$ fluids in silicate melts. Chem Geol 229(1-3):78-95

Paulatto M, Annen CJ, Henstock TJ, Kiddle EJ, Minshull TA, Sparks RSJ, Voight B (2012) Magma chamber properties from integrated seismic tomography and thermal modeling at Montserrat. Geochem Geophys Geosyst. https://doi.org/10.1029/2011G $\mathrm{C} 003892$

Pichavant M, Martel C, Bourdier J-L, Scaillet B (2002) Physical conditions, structure, and dynamics of a zoned magma chamber: Mount Pelée (Martinique, Lesser Antilles Arc). J Geophys Res 107(B5):2093. https://doi.org/10.1029/2001JB000315

Pichavant M, Poussineau S, Lesne P, Solaro C, Bourdier J-L (2018) Experimental parameterization of magma mixing: application to the $1530 \mathrm{AD}$ eruption of La Soufrière, Guadeloupe (Lesser Antilles). J Pet. https://doi.org/10.1093/petrology/egy030

Poussineau S (2005) Dynamique des magmas andésitiques: approche expérimentale et pétrostructurale; application à la Soufrière de Guadeloupe et à la Montagne Pelée. PhD thesis, Univ Orléans, p 300

Putirka KD (2008) Thermometers and barometers for volcanic systems. Rev Mineral Geochem 69(1):61-120

Roobol MJ, Wright JV, Smith AL (1983) Calderas or gravityslide structures in the Lesser Antilles island arc? J Volcanol Geotherm Res 19:121-134. https://doi.org/10.1016/03770273(83)90128-2

Samper A, Quidelleur X, Boudon G, Le Friant A, Komorowski J-C (2008) Radiometric dating of three large volume flank collapses in the Lesser Antilles Arc. J Volcanol Geotherm Res 176:485-492

Sigurdsson H (1972) Partly-welded pyroclast flow deposits in Dominica, Lesser Antilles. Bull Volcanol 36:148-163. https://doi. org/10.1007/BF02596987
Sigurdsson H, Carey SN (1981) Marine tephrochronology and quaternary explosive volcanism in the lesser antilles arc. In: Self S, Sparks RSJ (Eeds) Tephra studies. Reidel, Dordredcht, pp 255-280

Smith AL, Roobol MJ, Mattioli GS, Fryxel JE, Daly GE, Fernandez LA (2013) The volcanic geology of the mid-arc Island of Dominica, Lesser Antilles; the surface expression of an island-arc batholith. Geol Soc Am Spec Pap. https://doi.org/10.1130/2013.2496

Solano JMS, Jackson MD, Sparks RSJ, Blundy J, Annen C (2012) Melt segregation in deep crustal hot zones: a mechanism for chemical differentiation, crustal assimilation and the formation of evolved magmas. J Pet 53:1999-2026. https://doi.org/10.1093/petrology/ egs041

Solaro-Müller C (2017) Storage conditions and dynamics of magma reservoirs feeding the major pumiceous eruptions of Dominica (Lesser Antilles Arc). PhD thesis, Univ. Sorbone Paris Cité, p 330

Tamic N, Behrens H, Holtz (2001) The solubility of $\mathrm{H}_{2} \mathrm{O}$ and $\mathrm{CO}_{2}$ in rhyolitic melts in equilibrium with a mixed $\mathrm{CO}_{2}-\mathrm{H}_{2} \mathrm{O}$ fluid phase. Chem Geol 174:333-347

Thirlwall MF, Graham AM, Arculus RJ, Harmon RS, Macpherson CG (1996) Resolution of the effects of crustal assimilation, sediment subduction, and fluid transport in island arc magmas: $\mathrm{Pb}-\mathrm{Sr}-$ $\mathrm{Nd}-\mathrm{O}$ isotope geochemistry of Grenada, Lesser Antilles. Geochim Cosmo Acta 60:4785-4810

Villemant B, Boudon G (1998) Transition between dome-forming and Plinian eruptive style: $\mathrm{H}_{2} \mathrm{O}$ and $\mathrm{Cl}$ degassing behavior. Nature 392:65-69

Wadge G (1984) Comparison of volcanic production rates and subduction rates in the Lesser Antilles and Central America. Geology 12:555-558. https://doi.org/10.1130/0091-7613

Wadge G, Shepherd JB (1984) Segmentation of the Lesser Antilles subduction zone. Earth Planet Sci Lett 71:297-304. https://doi. org/10.1016/0012-821X(84)90094-3

Wallace PJ (2005) Volatiles in subduction zone magmas: concentrations and fluxes based on melt inclusion and volcanic gas data. J Volcanol Geotherm Res 140:217-240

Watson EB, Harrison M (1983) Zircon saturation revisited: temperature and composition effects in a variety of crustal magma types. Earth Planet Sci Lett 64(2):295-304

Webster JD (1997) Chloride solubility in felsic melts and the role of chloride in magmatic degassing. J Pet 38(12):1793-1807. https:// doi.org/10.1093/petroj/38.12.1793

Webster JD, Holloway JR (1988) Experimental constraints on the partitioning of $\mathrm{Cl}$ between topaz rhyolite melt and $\mathrm{H}_{2} \mathrm{O}$ and $\mathrm{H}_{2} \mathrm{O}+$ $\mathrm{CO}_{2}$ fluids: new implications for granitic differentiation and ore deposition. Geochem Comochim Acta 52(8):2091-2105

Webster JD, Kinzler RJ, Mathez EA (1999) Chloride and water solubility in basalt and andesite melts and implications for magmatic degassing. Geochem Comochim Acta 63(5):429-738

Webster JD, Baker DR, Aiuppa A (2018) Halogens in mafic and intermediate-silica content magmas. In: The role of halogens in terrestrial and extraterrestrial geochemical processes. Springer, Berlin, pp 307-430

Wilkinson JJ (2013) Triggers for the formation of porphyry ore deposits in magmatic arcs. Nat Geosci 6:917-925. https://doi. org/10.1038/ngeo1940

Yanagida Y, Nakamura M, Yasuda A, Kuritani T, Nakagawa M, Yoshida T (2018) Differentiation of a hydrous arc magma recorded in melt inclusions in deep crustal cumulate xenoliths from Ichinomegata Maar, NE Japan. Geochem Geophys Geosyst 19:838-864

Ziberna L, Green ECR, Blundy JD (2017) Multiple-reaction geobarometry for olivine-bearing igneous rocks. Am Mineral. https://doi. org/10.2138/am-2017-6154 